UDK: 616.932(497.5Dalmacija)"183/184"

Primljeno: 28.1.2021.

Prihvaćeno: 5. 5. 2021.

Izvorni znanstveni rad

https://doi.org/10.22586/pp.v40i60.15253

Maja Katušic *

Kristina Puljizević**

\title{
Da cholera morbus - epidemije kolere i protuepidemijske mjere u Dalmaciji 30-ih i 40-ih godina 19. stoljeća ${ }^{* * *}$
}

U radu se na temelju brojnih arhivskih izvora, novina te liječničkih zapisa promatraju i analiziraju epidemije kolere u Dalmaciji sredinom 19. stoljeća. Razmatra se razina saznanja o bolesti i protuepidemijske mjere, napose njihova učinkovitost te aktualnost s obzirom na postojeće i rastuće rasprave o etiologiji bolesti. U drugom dijelu rada kao primjer slučaja analizirana je epidemija kolere u Zadru 1849. godine. Na temelju zapisa o koleri u matičnim knjigama umrlih u Zadru prikazuje se broj, dobna, spolna i društvena struktura umrlih.

Ključne riječi: kolera, Dalmacija, Zadar, 1830-e, 1840-e, protuepidemijske mjere, matične knjige umrlih

\section{Uvod}

Kolera je akutna zarazna bolest kojoj je uzročnik bakterija Vibrio cholerae. Bakterija u crijevnom traktu izlučuje toksin koji izaziva teške simptome: tijelo povraćanjem i proljevom naglo i obilno gubi tekućinu (vodu i elektrolite); uslijed dehidracije dolazi do bolnoga grčenja mišića, sniženoga krvnog tlaka, otežane cirkulacije krvi te oslabjeloga pulsa. Osoba oboljela od kolere poprima karakte-

\footnotetext{
Maja Katušić, Hrvatski institut za povijest, Opatička 10, 10000 Zagreb, Republika Hrvatska, E-mail adresa: mkatusic@isp.hr

** Kristina Puljizević, Hrvatsko katoličko sveučilište, Ilica 242, 10000 Zagreb, Republika Hrvatska, E-mail adresa: kristina.puljizevic@unicath.hr

${ }^{* * *}$ Rad je nastao u sklopu projekta Tradicionalizam i inovacije u Dubrovniku od srednjeg vijeka do devetnaestog stoljeća (HRZZ IP-01-2018-5527).
} 
rističan izgled upalih obraza i očiju te plave kože. ${ }^{1}$ Transmisija bolesti odvija se neizravno, oralnim unosom bakterije u organizam preko vode ili hrane kontaminirane fekalnim otpadom oboljelih od kolere, tzv. fekalno-oralnom rutom. ${ }^{2}$

Termin „kolera” prisutan je već u Hipokratovu korpusu. Odnosio se na sporadičnu dijareju, a u tom su ga značenju koristili i drugi medicinski autoriteti staroga vijeka. U drugoj polovini 17. stoljeća u Londonu je podrazumijevao epidemiju općenito; kasnije, tijekom 19. stoljeća, korišten je za sporadične ili endemične epidemije dijareje koje su se u medicinskoj literaturi toga vremena također nazivale cholera nostras (naša kolera) ili, karakteristično za literaturu na talijanskom jeziku - cholera occidentale (zapadna kolera). Termin „azijska kolera” odnosio se isključivo na koleru koja se počevši od 1817. širila iz Indije. ${ }^{3}$ Često je u 19. stoljeću korišten i termin cholera-morbus, koji je mogao značiti sve oblike kolere. ${ }^{4} \mathrm{U}$ ovom radu, ako nije drugačije naznačeno, pod terminom kolera podrazumijevamo azijsku koleru.

Tijekom 19. stoljeća, kao i prije u prošlosti, europska društva pogađale su različite crijevne bakterioze poput dizenterije, pjegavoga ili trbušnoga tifusa. Toj skupini bolesti od početka 19. stoljeća svom silinom pridružila se kolera, a pratile su ju društvena stigma i socijalni nemiri. ${ }^{5}$ Kolera je do tada bila endemična $u$ indijskim pokrajinama, a po Europi i svijetu proširila se kada su za to stvoreni globalizacijski preduvjeti: razvojem željezničke mreže i bržom komunikacijom među velikim geografskim udaljenostima. Utvrđeno je sedam velikih pandemija kolere, od kojih je pet haralo u 19. stoljeću. ${ }^{6}$ Sredinom toga stoljeća medicinska struka i državne uprave još nisu imale točna saznanja o širenju kolere ni učinkovit način njezina zaustavljanja i liječenja.

Koža poprima plavu boju uslijed nedostatka kisika u krvi, a to stanje naziva se cijanoza. Reinhard S. Speck, „Cholera”, u: The Cambridge World History of Human Disease, ur. Kenneth F. Kiple (Cambridge: Cambridge University Press, 1993), 462, 464; Richard J. Evans, „Blue Funk and Yellow Peril: Cholera and Society in Nineteenth-Century France”, European History Quarterly 20 (1990), br. 1: 111-113; Frank Snowden, Epidemics and Society: From the Black Death to the Present (New Haven; London: Yale University Press, 2019), 235-239.

2 Speck, „Cholera”, 642.

3 Speck, „Cholera”, 642. O zapadnoj i azijskoj koleri vidi: Valentino Trigari, Memoria sopra i primi casi di Cholera-morbus che si manifestarono in Zara nel MDCCCXXXXIX con una opinione sul cholera in generale dell' anno detto (Split: Tip. M. V. Piperata e figlio, 1851).

4 Speck, „Cholera”, 642.

5 Richard J. Evans, „Epidemics and Revolutions: Cholera in Nineteenth-Century Europe”, Past \& Present 120 (1988), br. 1: 139-141; Mark Harrison, Disease and the Modern World: 1500 to the present day (Cambridge: Polity, 2004), 105-109; Tatjana Buklijaš, „Kolera: 'nova' bolest u doba revolucija”, Hrvatska revija 3 (2003), br. 1: 90-93.

6 Šesta pandemija započela je 1899. i završila 1920-ih. Čini se ipak da ne postoji konsenzus među povjesničarima medicine o točnim godinama završetka jedne i početka druge pandemije. Usp. primjerice: Speck, „Cholera”, 645-647; Roy Porter, The Greatest Benefit to Mankind: A Medical History of Humanity from Antiquity to the Present (London: Fontana Press, 1997), 402-404; Snowden, Epidemics and Society, 233. 
O pojedinim epidemijskim naletima kolere u hrvatskim zemljama u 19. stoljeću objavljeno je nekoliko istraživanja, koja se svako za sebe temelje na jednoj vrsti izvora. ${ }^{7}$ Istraživanjem epidemija kolere u Dalmaciji 30-ih i 40-ih godina 19. stoljeća te analizom epidemije kolere u Zadru 1849. obuhvaćeni su raznovrsni izvori. Tiskani proglasi i upute za vladanje državnih službenika i stanovnika za vrijeme kolere koje je sastavila dalmatinska vlada odražavaju reakcije struktura vlasti na epidemije u prva dva desetljeća epidemijskih valova kolere. Na temelju stručnih medicinskih tekstova problematizirat će se i razina saznanja o bolesti, pravovremenost mjera i njihova aktualnost s obzirom na globalnu situaciju. Kvantitativna analiza umrlih od kolere temelji se na upisima iz matičnih knjiga umrlih župa sv. Stošije, sv. Šime i sv. Ilije u Zadru, koji su se komparirali s podacima iz vladina glasila Glasnik dalmatinski te podacima iz literature, a pokazat će sezonsko kretanje epidemije 1849. te broj, dobna, spolna i društvena struktura umrlih.

\footnotetext{
Najčešće su analizirane matične knjige umrlih, na kojima se temelje radovi M. Bolonića o epidemiji kolere na Krku 1855. (Mihovil Bolonić, „Kužne bolesti u prošlosti otoka Krka (s posebnim osvrtom na koleru 1855. godine)", Krčki zbornik 6 (1975): 79-132), I. Ipšić o koleri u Drenovcima 1873. (Irena Ipšić, „Demografske i društveno-gospodarske posljedice epidemije kolere - primjer epidemije u Drenovcima 1873. godine", Scrinia Slavonica 10 (2010), br. 1: 527-545) te kraći rad V. Juzbašića o koleri u Bošnjacima 1913. (Vinko Juzbašić, „Kolera u Bošnjacima 1913. godine”, Hrašće 28 (2003): 76-80). Na temelju izvještaja župnika Savičente S. Bertoša opisao je epidemiju kolere 1855. u tom mjestu (Slaven Bertoša, „Zapisi o koleri u jednoj istarskoj župi god. 1855.”, Historijski zbornik XLI (1988): 245-251), a opsežnijom analizom izvještaja oružnika i liječnika te naredbi iz fonda Odjela za unutrašnje poslove Zemaljske vlade I. Despot rekonstruirao je epidemiju kolere 1913. u Banskoj Hrvatskoj (Igor Despot, „Kolera u Banskoj Hrvatskoj 1913. godine - mjere državne vlasti u prevenciji i suzbijanju epidemije”, Radovi Zavoda za hrvatsku povijest Filozofskoga fakulteta Sveučilišta u Zagrebu 45 (2013), br. 1: 59-70). Istraživanje S. Fatović-Ferenčić i M. Wokaunna o percepciji kolere 1886. u dolini Neretve temelji se na novinskim člancima (Stella Fatović-Ferenčić, Mario Wokaunn, „Poneretvlje kao patološki topos: tisak i politizacija sjećanja na doba kolere 1886. g.”, Liječnički vjesnik 134 (2012), br. 5-6: 186-191), a podrobniju analizu iste teme, donosi rad Mario Wokaunn, Stella Fatović-Ferenčić, Ivan Jurić, Marijo Bekić, "God's Punishment or Bad Strategy: Anti-Epidemic Measures in the Lower Neretva Basin at the Time of Cholera in 1886", Collegium Antropologicum 36 (2012), br. 3: 987-995. Na temelju analize raznih državnih spisa i liječničkih zapisa opširnu analizu epidemija kolere u Trstu i Istri tijekom 19. stoljeća obradio je R. Cigui (Rino Cigui, „Antiche e nuove paure: le epidemie di colera a Trieste e in Istria nel secolo XIX", Atti 38 (2008), br. 1: 429-504). Na ta se istraživanja naslanjaju i radovi U. Železnik, koja je obradila epidemije kolere na istarskom području, napose u Kopru (Urška Železnik, „Koper in kolera leta 1855: družbeno-demografski pogled v mestno tkivo", u: Bertošin zbornik. Zbornik u čast Miroslava Bertoše, knj. 2, ur. Ivan Jurković (Pula; Pazin: Sveučilište Jurja Dobrile u Puli; Državni arhiv u Pazinu, 2013), 583-603). Zaraznim bolestima na području Istre posvećen je istoimeni trojezični zbornik radova, a kolerom se bave sljedeći radovi: Urška Železnik, „Kolera in urbano prebivalstvo: Koper in obalna mesta v 19. stoletju”, 49-68, Euro Ponte, „Il colera del 1886 a Muggia”, $79-87$ i Amir Muzur, „Istarski sveti Rok: od zaštitnika od kuge do zaštitnika od kolere”, 69-78, u: Epidemične bolezni v Istri 19. in 20. stoletju = Le malattie epidemiche in Istria tra ' 800 e ' $900=$ Zarazne bolesti u Istri tijekom 19. i 20. stoljeća, ur. Ante Škrobonja (Koper: Humanistično društvo Histria, 2010).
} 


\section{Prve reakcije vlasti u Dalmaciji na pojavu kolere u Habsburškoj Monarhiji (1830. - 1835.)}

Rasprava o uzrocima bolesti vodila se krajem 18. i tijekom 19. stoljeća u ekonomskim i političkim jednako kao i u medicinskim krugovima. Karantenske odredbe opterećivale su nacionalne ekonomije i brzorastuća industrijska društva zapadne Europe, koja su se temeljila na slobodnoj trgovini. U fokusu rasprave našli su se uzroci različitih groznica ${ }^{8}$ za koje se činilo da se javljaju u epidemijskim valovima unatoč karantenskim mjerama. Izbijanje nekoliko epidemija žute groznice u drugoj polovini 18. stoljeća u Philadelphiji ${ }^{9}$ unatoč strogim mjerama za trgovce dovelo je do zaključka da ta bolest nije zarazna, nego je posljedica mijazmi, neživih čestica nastalih isparavanjem truleži koje lebde zrakom. ${ }^{10}$ Takvo antikontagionističko shvaćanje činilo je karantenu suvišnom, a za sprječavanje epidemija predlagale su se sanitarne mjere poput uređenja odvodnje otpadnih voda, odgovarajuće opskrbe čistom vodom, osiguravanja prozračnosti i čistoće prostora (unutrašnjih i vanjskih). Među antikontagionistima bilo je medicinskih stručnjaka, no i političara, činovnika te raznih poslovnih ljudi koji su imali interesa u dokidanju po njihovu mišljenju zastarjelih karantenskih odredbi. Sustav karantene, segregacija oboljelih od zdravih te fumigacija sumnjivih predmeta i prostora temeljili su se na teoriji da se zarazne bolesti šire kontaktom. ${ }^{11}$

Pojavom kolere u Europi 1831. nastavila se rasprava o etiologiji bolesti, o kojoj su ovisile i mjere koje će države provesti da bi zaustavile njezino širenje. Primjerice, kada se 20 -ih godina proširila kolera iz azijskoga dijela Rusije, liječnici su nakon početne skepse ipak ustanovili njezinu zaraznost te uveli karantenu. No centralna Rusija i Sankt Peterburg mjere su uveli kasno, 1830., kada se epidemija već razbuktala, što je dio medicinskih stručnjaka navelo na zaključak da je karantena

\footnotetext{
8 Stanovništvo u 19. stoljeću, posebno u industrijskim gradovima, često su pogađale različite groznice. Pored respiratornih viroza kao što su prehlada i gripa, česte su bile ospice, šarlah, difterija, vodene kozice te enterične groznice s proljevom i povraćanjem, posebno trbušni tifus. R. Porter, The Greatest Benefit to Mankind, 402.

9 Harrison, Disease and the Modern World, 97-100. Usp. Roderick E. McGrew, Russia and the Cholera (Madison: University of Wisconsin Press, 1965), posebice 41-97.

10 Teorija o mijazmama kao uzroku epidemija različitih bolesti potječe iz Hipokratova vremena. Utjecaj onečišćene atmosfere na zdravlje opisan je u djelu iz Hipokratova korpusa $O$ zraku, vodi $i$ tlu. Teoriju je tijekom vremena nadograđivalo i upotpunjavalo nekoliko istaknutih medicinskih autora. Dorothy Porter, Health, Civilization and the State: A history of public health from ancient to modern times (London: Routledge, 1999), 15, 82.

11 Shvaćanje da se određene bolesti šire kontaktom najranije je zabilježeno u Bibliji pri opisima lepre, a u Hipokratovu korpusu takav se način zaraze ne spominje. Najkonkretniju ideju te teorije u ranome modernom razdoblju ponudio je Girolamo Fracastoro u svojoj knjizi De contagione et contagiosis morbis iz 1546., prema kojoj je uzrok bolesti živo zarazno „sjeme”. U kasnijim je interpretacijama i ta teorija doživjela brojna tumačenja i nadogradnje. D. Porter, Health, Civilization and the State, 81-82.
} 
neuspješna te da kolera nije zarazna. ${ }^{12}$ Etiologija kolere bila je nejasna tijekom prve polovine 19. stoljeća, a zbog izostanka egzaktnih pokazatelja koji bi poduprli bilo koju od dviju teorija granica između kontagionizma i antikontagionizma često je bila labava, a same teorije podložne različitim tumačenjima, pa je većina liječnika smatrala da su uzroci bolesti kombinacija raznih faktora. U tom su smislu mnogi liječnici, ali i drugi koji su se bavili tim pitanjem, vodećim uzrokom kolere i drugih bolesti smatrali siromaštvo. ${ }^{13}$

Istraživanja Johna Snowa tijekom epidemije kolere u Londonu 1849., koja su pokazala da se kolera širi onečišćenom vodom, počela su se prihvaćati od 1860 -ih, ${ }^{14}$ a punu potvrdu o uzroku i načinu prijenosa kolere donijelo je Kochovo istraživanje i razvoj bakteriologije 1880 -ih. ${ }^{15}$

Europu je 1830-ih i 1840-ih pogodilo više epidemijskih valova kolere. Iako su neke države imale autoritativniji pristup provođenju javnozdravstvenih odredbi (poput Rusije ili Pruske), a druge slobodniji, laissez faire način (poput Velike Britanije), pri prvim izbijanjima kolere u svim su zemljama uvedene karantenske odredbe i druge tradicionalne protuepidemijske mjere opreza. ${ }^{16} \mathrm{U}$ nekim su sredinama, poput Francuske, antikontagionistička stajališta bila utjecajna, no njihovi se prijedlozi za poboljšanje općih higijenskih uvjeta (kanalizacija, pitka voda, asanacija i sl.) nisu mogli trenutačno primijeniti, pa su se u tim prvim naletima kolere oslonili na već dostupne mehanizme karantene i sanitarne kordone. ${ }^{17} \mathrm{Ha}-$ bsburška Monarhija bila je jedna od zemalja s autoritativnom upravom, za koje se u tradicionalnoj povijesno-medicinskoj literaturi smatra da imaju čvršći model upravljanja javnim zdravstvom (uključujući epidemije), s više kontrole i većim utjecajem države, te da je to posljedica stila upravljanja općenito. ${ }^{18}$ No povrh

12 Harrison, Disease and the Modern World, 101.

13 Deborah Brunton, „Dealing with Disease in Populations. Public Health, 1830-1880”, u: Medicine Transformed. Health, Disease and Society in Europe, ur. Deborah Brunton (Manchester: University Press, 2004), 191-192; D. Porter, Health, Civilization and the State, 83-87; Harrison, Disease and the Modern World, 109-117.

14 Harrison, Disease and the Modern World, 103-104; R. Porter, The Greatest Benefit to Mankind, 412-413.

${ }_{15}$ Koch je objavio svoje istraživanje na izolaciji bakterije Vibrio cholerae 1883. godine. R. Porter, The Greatest Benefit to Mankind, 437.

16 Evans, „Epidemics and Revolutions”, 139-141.

17 Harrison, Disease and the Modern World, 101-102.

18 Habsburška je Monarhija pod utjecajem kameralizma podredila javno zdravstvo čvršćoj kontroli države tijekom druge polovine 18. stoljeća. Vidi: Ivana Horbec, Zdravlje naroda - bogatstvo države. Prosvijećeni apsolutizam i počeci sustava javnoga zdravstva u Hrvatskoj (Zagreb: Hrvatski institut za povijest, 2015); Robert Skenderović, „Zdravstvene reforme Marije Terezije u slavonskom Provincijalu i Generale normativum sanitatis iz 1770.", Scrinia Slavonica 5 (2001), br. 1: 115-143. Takav način upravljanja javnim zdravstvom pokušao se primijeniti i u Dalmaciji nakon habsburškoga stjecanja te pokrajine krajem 18. i početkom 19. stoljeća. Kristina Puljizević, U ženskim rukama. Primalje i porođaj u Dubrovniku (1815-1918) (Zagreb; Dubrovnik: Zavod za povijesne znanosti HAZU u Dubrovniku, 2016), 53-55, 61-65. 
toga Habsburška Monarhija dijelila je dugačku granicu s Osmanskim Carstvom, koje je zbog nepostojećih protuepidemijskih mjera i komunikacije $s$ azijskim zemljama uvijek predstavljalo epidemiološku opasnost. ${ }^{19} \mathrm{U}$ toj je maniri dalmatinska vlada već 1831. tiskala nekoliko uputa za slučaj kolere te opet opširne upute $1835 .{ }^{20}$ Iako se epidemija tada još nije bila proširila u pokrajini (prva epidemija kolere u Dalmaciji buknula je 1836. godine). ${ }^{21} \mathrm{U}$ uputama se najčešće koristi izraz colera-morbus te jednom colera asiatico, a colera occidentale se ne spominje, pa je sasvim izvjesno da se upute odnose na azijsku koleru koja se, slijedeći putanju druge pandemije, nakon Krakova, Moskve, Varšave i Rige prvi put proširila Berlinom i Bečom u kolovozu 1831. godine. ${ }^{22}$ Uputama su propisane odgovornosti i preporuke za sve djelatnike u lokalnim upravama, posebno sanitarne službenike, bolničare, medicinsko osoblje te njegovatelje bolesnika u obiteljima. Prije svega, predviđena je razgranata mreža službenika koji su nadzirali pojavu epidemije i pokušavali kontrolirati njezino širenje. Propisane su mjere predostrožnosti koje je trebalo poduzeti prije pojave kolere i mjere za slučaj kada se kolera već razvije. U prvom slučaju veliku odgovornost imali su poglavari određenih četvrti (Capo-quartiere) imenovani među „poštenim građanima”, koji su trebali uočiti pojavu epidemije te su imali široke ovlasti: obilazak i pregled privatnih kuća, gostionica i trgovina i sl. ${ }^{23}$ Nakon razbuktavanja epidemije veću odgovornost imalo je službeno sanitarno osoblje, okružni poglavari te poglavari sela i svećenici (gdje nema sanitarne komisije). ${ }^{24}$ Radi se o sustavu strogoga nadzora higijenskih, zdravstvenih i epidemijskih prilika među stanovništvom koji provode državne strukture - medicinska policija, koji je za Habsburšku Monarhiju krajem 18. stoljeća nadogradio i promovirao zdravstveni reformator Johann Peter Frank..$^{25}$ Štoviše, termin polizia sanitaria često se spominje u analiziranim dokumentima.

19 Harrison, Disease and the Modern World, 43, 102-103; Horbec, Zdravlje naroda - bogatstvo države, 85-120; Gunther E. Rothenberg, „The Austrian Sanitary Cordon and the Control of the Bubonic Plague: 1710-1871", Journal of the History of Medicine 28 (1973), br. 1: 15-23.

20 Od ukupno 17 sačuvanih tiskanih objava za vrijeme austrijske uprave u Dalmaciji (1813. - 1918.) koje se izravno tiču kolere, čak ih je 11 tiskano tijekom prvoga naleta kolere u Habsburškoj Monarhiji od 1830. do 1835., od toga osam 1831. godine. Vidi: Ivan Fantina, HR DAZD - 386 Štampe 1488. 1940. (Zadar: Hrvatski državni arhiv, 2006). Sadržaj uputa često se ponavlja, a za ovaj rad posebno su analizirani sljedeći opširni naputci: Hrvatska (dalje: HR) - Znanstvena knjižnica Zadar (dalje: ZKZD) - Istruzione per le II. RR. Commissioni locali di sanita, gli II. RR. Capitanati circolari e le alter autorita politiche rispetto al Colera morbus, Zara, 25 settembre 1831, Misc. B 8198 (dalje: Misc. B 8198); HRZKZD - Istruzione per gli assistenti degli ammalati di colera morbus, Zara, 14 ottobre 1831, Misc. B 8199 (dalje: Misc. B 8199); HR-ZKZD - Avvertimento diretto alla popolazione Dalmata sul Colera, Zara, 16. ottobre 1835, Misc. B 8212 (dalje: Misc. B 8212).

${ }^{21}$ Francesco Lanza, Relazione nosografico-statistica sull'epidemia colerosa, che invase la Dalmazia nell' anno 1836 (Trieste: Weis, 1838), 10.

22 Speck, „Cholera”, 646.

23 HR-ZKZD, Misc. B 8198, čl. 1.-10.

24 HR-ZKZD, Misc. B 8198, čl. 38., passim.

25 Horbec, Zdravlje naroda - bogatstvo države, 227-239; Puljizević, U ženskim rukama, 53-55, 61-65. 
Sadržaj uputa zrcali svu kompleksnost rasprave o etiologiji kolere. ${ }^{26}$ Najviše se odredbi temelji na teoriji o zarazi, tj. širenju bolesti kontaktom. Više je puta upozoreno na štetnost prenapučenih stambenih prostora jer je „iskustvo pokazalo” da ta okolnost pogoduje širenju bolesti. ${ }^{27}$ Zatim, osobu oboljelu od kolere trebalo je izdvojiti od ostalih članova obitelji. Ukućanima koji nisu sudjelovali u njezi oboljeloga savjetovalo se neka izbjegavaju kontakt sa zaraženim i ne dotiču stvari koje je on dodirnuo. Medicinskom osoblju koje se skrbi o oboljelima preporučuje se da se čuvaju udisanja „daha bolesnika ili pare koja je nastala slučajnim uklanjanjem njegova pokrivača" ${ }^{28} \mathrm{U}$ tom se slučaju bolničarkama savjetuje progutati slinu, žvakati bobice kleke ili lovora, korijen anđelike, iđirot ili narančinu koru. ${ }^{29}$ Kuća u kojoj je bilo zaraženih izolirala se od ostalih kuća u mjestu. U slučaju daljnjega širenja bolesti izoliralo se cijelo mjesto ili područje, što se provodilo uz pomoć vojske i civilne straže. ${ }^{30}$ Sami stanovnici upućivali su se na redukciju međusobnih kontakata, a svi koji su bili u kontaktu sa zaraženim bili su podložni posebnom nadzoru. ${ }^{31}$ Slične mjere održavanja fizičke distance propisane su $\mathrm{u}$ slučaju prijevoza bolesnika u bolnice, transporta umrlih od kolere te njihova pogreba. ${ }^{32} \mathrm{U}$ slučaju epidemije u susjednim područjima naloženo je uvođenje karantene i segregacija „kao što je to slučaj u vrijeme kuge” te se, da bi se nastavila komunikacija i trgovina, predviđalo uspostavljanje raštela. ${ }^{33}$

Povrh mjera odvajanja i fizičke distance bila je propisana i svojevrsna dezinfekcija fumigacijom i pranjem, pri čemu su se koristili klor i ocat. Ti su se postupci uglavnom odnosili na čišćenje prostora i predmeta. Primjerice, kuće u kojima se pojavila kolera pročišćavane su isparavanjem klora ili octa. Klor se mogao dobiti iz javnoga fonda uz recept liječnika ili kirurga. Na raštelima su se provodili slični postupci uobičajeni na sanitarnim kordonima i u lazaretima tijekom prijašnjih epidemija kuge: roba „osjetljiva” za širenje zaraze (vuna, svila, krzno i sl.) nije se

\footnotetext{
${ }^{26}$ Negdje se u uputama, čak i u istom članku, daju preporuke od kojih se jedna može razumjeti kao mjera opreza zbog zaraze, a već sljedeća kao uputa za otklanjanje mijazmi. Primjerice, u odjeljku II, čl. 2. Upozorenja stanovništvu Dalmacije glede kolere preporučuje se da u spavaćim sobama ne spava više od troje ljudi (bliskim kontaktom širi se zaraza), a već u idućim rečenicama savjetuje se stambene prostore provjetravati nekoliko puta dnevno, pročišćavati zrak isparavanjima otopine octa te iz prostorija ukloniti sve što uzrokuje loš miris i štetna isparavanja (plijesan, fermentacija) „kako bi se sačuvao čist zrak bez heterogenih čestica”. HR-ZKZD, Misc. B 8212, odjeljak II, čl. 2.

27 HR-ZKZD, Misc. B 8198, čl. 13.; HR-ZKZD, Misc. B 8212, odjeljak II, čl. 2.

28 HR-ZKZD, Misc. B 8199, čl. 22.

29 HR-ZKZD, Misc. B 8199, čl. 22.

30 HR-ZKZD, Misc. B 8198, čl. 5., 24., 32.

31 HR-ZKZD, Misc. B 8198, čl. 5., 24.

32 Primjerice, za osobe koje transportiraju oboljele ili umrle od kolere predviđeno je zaštitno odijelo i rukavice od „voštane tkanine”, a prijevoz se mora obaviti prometnicama s manje prometa i kroz nenaseljena mjesta. HR-ZKZD, Misc. B 8198, čl. 29., 30., 31.
}

33 HR-ZKZD, Misc. B 8198, čl. 20. 
prihvaćala, ostala se roba ispirala, a plaćalo se preko posude s vodom i octom u koju se uranjao kovani novac. Pisma su se dimila nad zapaljenom mješavinom sumpora, salitre i slame. ${ }^{34}$ Propisana je i osobna dezinfekcija: muškarci koji su prevozili oboljele od kolere u bolnice trebali su između usta i nosa držati spužvu natopljenu mješavinom vode i octa, a nakon dostavljanja pacijenta u bolnicu savjetovano im je da istom otopinom isperu lice, ruke i usta. ${ }^{35}$ Bolničarkama koje su se skrbile o oboljelima također je bilo preporučeno često prati ruke, lice, nosnice i usta octom. ${ }^{36}$

Pojedine odredbe ipak su se temeljile na teoriji o mijazmama kao uzrocima bolesti. U kućama je trebalo održavati čistoću, sobe su se trebale provjetravati nekoliko puta dnevno, sav je otpad trebalo ukloniti iz dvorišta te je općenito svaki stanovnik trebao izbjegavati izbacivanje nečistoće i smeća u blizini svoje kuće i u svojoj četvrti. ${ }^{37}$ Svako je domaćinstvo, uz propisani oprez u nabavci i spravljanju hrane za obitelj, trebalo strogo paziti da iz kuće izbace trulu i pljesnivu hranu te onu sklonu fermentaciji. ${ }^{38}$

Naposljetku, pojedine su odredbe propisane u skladu s činjenicom da se bolest više širila među siromašnim stanovništvom te razmišljanjima da je siromaštvo jedan od njezinih glavnih uzroka. Prosjačenje i pokućarenje bilo je strogo zabranjeno. Prosjaci i lutalice predavani su policiji, uklanjani s ulice u ubožišta ili kakav drugi smještaj određen za tu svrhu, a ako su oboljeli od kolere, zbrinjavali su se „bez gubitka vremena” u unaprijed pripremljene bolnice za oboljele od kolere. ${ }^{39}$ Određeno je da se u takve bolnice hospitaliziraju i ostali koji nisu imali svoj dom poput služinčadi, naučnika, sitnih trgovaca i nosača. Sanitarni službenici bili su dužni ublažiti, koliko je to moguće, njihovu averziju prema bolnicama i uvjeriti ih da će se u bolnici prije oporaviti. ${ }^{40}$ Bolnice za oboljele od kolere, ubožišta i mjesta u koja su smješteni siromasi trebali su biti nadzirani da bi se poštovale sve mjere opreza i čistoće. ${ }^{41}$ Ipak, da se ne bi opteretio sustav za socijalnu pomoć, preporučivalo se siromasima naći posao. ${ }^{42}$ Prisilna hospitalizacija i strogi nadzor provodili su se nad siromašnim slojevima i u drugim krajevima Europe, što je dovelo do buntovnih reakcija. ${ }^{43}$

\footnotetext{
34 HR-ZKZD, Misc. B 8198, čl. 21.

35 HR-ZKZD, Misc. B 8198, čl. 30.

${ }^{36}$ HR-ZKZD, Misc. B 8199, čl. 22.

3 HR-ZKZD, Misc. B 8198, čl. 2.

38 HR-ZKZD, Misc. B 8198, čl. 3.; HR-ZKZD, Misc. B 8212, odjeljak II, čl. 2.

39 HR-ZKZD, Misc. B 8198, čl. 6., 14.

40 HR-ZKZD, Misc. B 8198, čl. 28.

${ }^{41}$ HR-ZKZD, Misc. B 8198, čl. 15.

${ }^{42}$ HR-ZKZD, Misc. B 8198, čl. 14.

${ }^{43}$ Evans, „Epidemics and Revolutions”, 136-139; Harrison, Disease and the Modern World, 107-108.
} 
Terapijske metode opisane u uputama za osobe (bolničarke ili ukućane) koje pomažu bolesnicima temeljile su se na humoralnoj medicini. Teorija utemeljena $u$ Hipokratovo vrijeme, po kojoj zdravlje čovjeka ovisi o individualnom balansu tjelesnih tekućina (krv, sluz, crna i žuta žuč) te ostalih vrijednosti povezanih s njima (vlažnost, toplina, godišnje doba, životne navike i mnoštvo drugih), ${ }^{44} \mathrm{zadr}$ žala se u medicinskoj praksi do druge polovine 19. stoljeća. ${ }^{45}$ Primjerice, sastavljači uputa iz 1835. izbjegli su opisati simptome bolesti (esibire un ritratto della malattia) koji bi odgovarali svakom pojedinačnom slučaju jer se oni razlikuju; ovise o godišnjem dobu, geografskim osobitostima te dobi, fizičkom temperamentu i osobnosti (morale) oboljeloga ${ }^{46} \mathrm{~S}$ obzirom na humoralni koncept bolesti cilj liječenja bilo je vraćanje ravnoteže tjelesnih tekućina, određenoga stupnja topline i vlage u tijelo oboljelog te je uključivalo poseban režim prehrane, tjelesne aktivnosti (ili mirovanja), propisivanje različitih pripravaka i postupaka. Najčešće su ipak propisivani emetici, purgativi i venesekcija da bi se tijelo temeljito očistilo od viška ili od pokvarenih tjelesnih tekućina. ${ }^{47}$

Prije dolaska liječnika njegovateljice su se trebale potruditi vratiti tjelesnu toplinu oboljeloga i potaknuti znojenje grijanjem bolesnikova tijela ili masažom. Opširno i detaljno opisani postupci ${ }^{48}$ smatrani su ključnim za ozdravljenje i zacijelo su bili fizički zahtjevni za njegovateljice, koje se poticalo da ne odustaju i da nastave s utopljivanjem oboljeloga šest do osam sati jer je iskustvo pokazalo da su se nakon tako pružene pomoći ponekad „probudili nesretnici za koje se vjerovalo da su već preminuli”. ${ }^{49}$ Protiv bolnih grčeva mišića i bolova u trbuhu stavljali su

\footnotetext{
44 R. Porter, The Greatest Benefit to Mankind, 55-62; Snowden, Epidemics and Society, 240.

${ }_{45}$ Medicina je tijekom stoljeća dolazila do novih i vrijednih saznanja. Ipak, u praksi (terapiji) stvari su se sporo mijenjale, što dokazuju i analizirane upute. Vidi primjerice: R. Porter, The Greatest Benefit to Mankind, 3-13; Harrison, Disease and the Modern World, 31-33.

${ }^{46}$ HR-ZKZD, Misc. B 8212, odjeljak I. Dalje u dokumentu ipak se navode prvi simptomi bolesti: „tupa bol u glavi, vrtoglavica, težina u želucu, sveopća malodušnost, lagano drhtanje u leđima i bolovi u trbuhu”, a poslije i ostali: „nasilno povraćanje i proljev vodenaste i bjelkaste materije, bolovi u želucu i donjem dijelu trbuha, grčeviti osjećaji u stopalima, mišićima i rukama.” HR-ZKZD, Misc. B 8212, odjeljak III.

47 Harrison, Disease and the Modern World, 17-19.

${ }_{48}$ Za utopljivanje su se koristile zagrijane tkanine, vruća voda u zemljanim zdjelama, vreće napunjene pijeskom, mekinjama ili vrućim pepelom te zagrijane cigle; ti su se predmeti stavljali na struk, između nogu i ispod pazuha oboljelog. Ako se tijelo bolesnika ipak ne bi zagrijalo i počelo znojiti, njegovateljica bi morala prijeći na masiranje i trljanje tijela. Tijelo oboljeloga trljalo se tkaninom (raša, flanel) ili čekinjama umočenim u dobro zagrijan ocat, vino ili rakiju, a u nedostatku tih tekućina grijala se voda u koju se dodavao naribani hren, papar ili gorušica u prahu, zatim aromatično bilje ili kamfor. Oboljeli nije smio biti izložen svježem (hladnom) zraku, no glava mu nije smjela biti pokrivena. Pokrivanje glave bolesnika preporučivalo se tek kad izbije znoj. HR-ZKZD, Misc. B 8212, odjeljak III; HR-ZKZD, Misc. B 8199, čl. 5.-12.
}

49 HR-ZKZD, Misc. B 8199, čl. 11. 
se oblozi od gorušice. ${ }^{50}$ Opisan je postupak klistiranja oboljelog, no bez navedenih indikacija. ${ }^{51}$ Preporučena hrana i piće također su imali svrhu utopliti tijelo i umiriti silinu bolesti. Svakih pola sata oboljelom je trebalo davati topli čaj od kamilice, matičnjaka, mente, majčine dušice, kadulje ili sljeza. ${ }^{52}$ Preporučene su i mesna juha bez masti s celerom i peršinom te juha od vina, koje su se smatrale vrlo blagotvornima za bolesni želudac. ${ }^{53}$

Uputama iz 1831. i 1835. generalno su se preporučivale sve dotad poznate i u praksi primjenjivane mjere opreza i postupanja u slučajevima epidemija te su odraz suočavanja s novom i nepoznatom zarazom. Ipak, u idućem razdoblju upravljanju nadolazećim epidemijama kolere u Dalmaciji pristupilo se na drugačiji način.

\section{Zaokret u upravljanju epidemijama kolere u Dalmaciji (1836. - 1849.)}

U jeku prve epidemije kolere u Dalmaciji 1836. godine ${ }^{54}$ dalmatinska vlada objavila je Oznanjenje, kojim je kratko i odlučno naređeno da se ustanovljene karantene i drugi postupci izolacije odmah uklone te je tada zabranjeno i daljnje uspostavljanje bilo kakvih oblika segregacije. ${ }^{55}$ Štoviše, takvi su postupci proglašeni štetnima za opće zdravlje i korist puka. ${ }^{56}$ Međutim, sastavljači Oznanjenja kao da nisu bili sigurni da se zaista radi o koleri. Epidemiju koja se tada proširila nazvali su gastro-enteričkom bolešću s obilježjima „serdobolje ili kolere” (pošljica nemochi gastro-enterike s' bilizim od serdobolje illi kolere), ${ }^{57}$ pri čemu je srdobolja bila

\footnotetext{
${ }^{50}$ HR-ZKZD, Misc. B 8212, odjeljak III; HR-ZKZD, Misc. B 8199, čl. 17.

51 Tekućina kojom su se klistirali oboljeli pripremala se kuhanjem sljeza ili mekinja u zasoljenoj vodi. Smjesa se filtrirala kroz komad tkanine, zatim se dodavalo malo ulja te se još topla tekućina stavljala u špricu. Postupak uvođenja klizme opisan je detaljno da se ne bi „oštetio nijedan unutarnji dio”. HRZKZD, Misc. B 8212, odjeljak III; HR-ZKZD, Misc. B 8199, čl. 16.

52 HR-ZKZD, Misc. B 8212, odjeljak III; HR-ZKZD, Misc. B 8199, čl. 4.

53 Juha od vina pripremala se kuhanjem pola čaše vina i mnogo vode, šećera i malo cimeta. Dodavala su se dva tučena žumanjka te se juha prelijevala preko krišaka prepečenoga kruha. HR-ZKZD, Misc. B 8212, odjeljak III; HR-ZKZD, Misc. B 8199, čl. 14.-15.

54 Epidemija je prema Lanzi počela 19. srpnja, a završila 8. prosinca 1836. godine. Lanza, Relazione nosografico-statistica sull'epidemia colerosa, 77.

55 HR - Državni arhiv u Zadru, Zadar (dalje: DAZD) - fond 386 - Štampe, kut. 42, sv. 60, Zadar, 20. kolovoza 1836. Obznana C. K. Vlade za Dalmaciju glede postupka za slučaj sumnje neke zarazne bolesti.

56 HR-DAZD-386-Štampe, kut. 42, sv. 60, Zadar, 20. kolovoza 1836. Obznana C. K. Vlade za Dalmaciju glede postupka za slučaj sumnje neke zarazne bolesti.

57 HR-DAZD-386-Štampe, kut. 42, sv. 60, Zadar, 20. kolovoza 1836. Obznana C. K. Vlade za Dalmaciju glede postupka za slučaj sumnje neke zarazne bolesti.
} 
pučki naziv za dizenteriju. ${ }^{58} \mathrm{Ni}$ u opširnijoj Obznani o suzbijanju zaraznih bolesti (općenito) koju je vlada tiskala mjesec dana nakon Oznanjenja ne stoji točan naziv bolesti koja je poprimila epidemijske razmjere. ${ }^{59}$ Vlada je "nakon nekoliko mjeseci iskustva sa dominantnom epidemijskom bolesti" Obznanom propisala određene protuepidemijske mjere. One su bile opsegom skromnije od prije analiziranih i uglavnom su ponovile slične odredbe. Uspostavljene su odgovornosti lokalnih vlasti, izvanrednoga zdravstvenog povjerenstva i medicinskoga osoblja u provedbi mjera kojima je trebalo ograničiti širenje te bolesti. Mjere više nisu uključivale karantenske odredbe te su se odnosile na održavanje čistoće ulica i kuća, nadzor tržnica ${ }^{60}$ pročišćavanje prostora u kojima su boravili oboljeli fumigacijom, dezinfekcijom, pranjem rublja i posteljine ${ }^{61}$ te postupanje s preminulima, ${ }^{62}$ čime se fokus upravljanja epidemijom usmjerio na antikontagionističku teoriju i moguće, premda se to nigdje izrijekom ne kaže, na teoriju prema kojoj se radi o „zapadnoj koleri” (colera occidentale) koja, prema tadašnjim shvaćanjima, nije zarazna i posljedica je lokalnih atmosferskih prilika. Možemo samo pretpostaviti (jer za to nemamo izravne dokaze) da izbjegavanje izjašnjavanja o kojoj se bolesti radi i ukidanje karantenskih i segregacijskih odredbi 1836. ima veze s pogodovanjem trgovačkom lobiju kako je to bio slučaj i drugdje u europskim zemljama. ${ }^{63}$ Medicinsko-znanstvena istraživanja u to vrijeme još nisu pouzdano dokazala nijednu teoriju o etiologiji kolere. Konsenzus nije postojao ni među dalmatinskim liječnicima. Splitski liječnik Francesco Lanza u svojoj je knjizi temeljito opisao prvi epidemijski nalet kolere u Dalmaciji 1836. godine; iako koristi izraz cholera-morbus, bez dvojbe opisuje „azijsku koleru”, a „zapadnu” uopće ne spominje. ${ }^{64}$ Smatrao je da je kolera upala gastrointestinalnoga trakta koja se brzo

58 „Srdobolja”, Hrvatska enciklopedija, mrežno izdanje (Leksikografski zavod „Miroslav Krleža”), pristup ostvaren 20. 10. 2020., https://enciklopedija.hr/natuknica.aspx?id=57577.

${ }_{59}$ HR-DAZD-386-Štampe, kut. 42, sv. 62, Zadar, 21. rujna 1836. Obznana C. K. Vlade za Dalmaciju o osnutku izvanredne komisije za suzbijanje kužnih bolesti i odredbe u pogledu toga.

${ }^{60}$ HR-DAZD-fond 386-Štampe, kut. 42, svezak 62, Zadar, 21. rujna 1836. Obznana C. K. Vlade za Dalmaciju o osnutku izvanredne komisije za suzbijanje kužnih bolesti i odredbe u pogledu toga., članak 4. Na tržnicama se posebno pazilo da se ne prodaje nezrelo voće te pokvareno meso i brašno.

${ }^{61}$ HR-DAZD-fond 386-Štampe, kut. 42, svezak 62, Zadar, 21. rujna 1836. Obznana C. K. Vlade za Dalmaciju o osnutku izvanredne komisije za suzbijanje kužnih bolesti i odredbe u pogledu toga, članak 2 .

${ }^{62}$ HR-DAZD-fond 386-Štampe, kut. 42, svezak 62, Zadar, 21. rujna 1836. Obznana C. K. Vlade za Dalmaciju o osnutku izvanredne komisije za suzbijanje kužnih bolesti i odredbe u pogledu toga, članak 1. Pokojnici su se morali ostaviti na krevetu barem tri sata nakon čega su mogli biti prevezeni u poseban prostor (kuću, mrtvačnicu). Također, određeno je zbrinjavanje maloljetnika kojima su roditelji oboljeli ili preminuli od „vladajuće bolesti“ kod rodbine ili susjeda te primanje socijalne naknade. Obznana C. K. Vlade za Dalmaciju o osnutku izvanredne komisije za suzbijanje kužnih bolesti, članak 5 .

${ }^{63} \mathrm{U}$ europskim zemljama u kojima su zbog strogih protuepidemijskih odredbi oštećeni trgovački interesi, mjere su se relaksirale. Evans, „Epidemics and Revolutions”, 140-141.

${ }^{64}$ Lanza, Relazione nosografico-statistica sull'epidemia colerosa, 47, 52, 74. 
širi abdomenom, na prsa i mozak, te uzrokuje neravnotežu „humoralne mase”. ${ }^{65}$ Mislio je da je kolera zarazna bolest koja se može javiti sporadično, no u određenim atmosferskim uvjetima kao što su vrlo hladno i vlažno vrijeme može postati epidemijska, i ponudio je brojne primjere iz svoje prakse kojima dokazuje svoj stav. ${ }^{66}$ Istovremeno je oštro kritizirao autora članka „Kolera se ne širi zarazom” koji je izašao u polutjedniku Gazzeta di Zara u rujnu 1836. godine. Autor je članak zaključio rečenicom: „Svaka imalo obrazovana/napredna (sviluppata) osoba neće koleru smatrati zaraznom bolešću." Lanza je dao naslutiti da se radi o liječniku koji je obavljao praksu na Pagu, u čije je izvještaje o začuđujuće maloj smrtnosti od kolere ozbiljno sumnjao, te je zaključio da je on „valjda jedina obrazovana/napredna osoba na svijetu". ${ }^{67}$

Kada se kolera 1849. ponovno raširila Dalmacijom, vladajuće strukture, lokalne zdravstvene službe i medicinsko osoblje te stanovništvo već su imali određeno iskustvo u borbi protiv te bolesti. Štoviše, u Naputku o postupanju „u slučaju zaraznih bolesti, osobito kolere" iz 1848. stoji da koleru više ne treba smatrati stranom bolešću nego autohtonom te da je to bolest „slična uobičajenoj dizenteriji”. ${ }^{8}$ Bolest se tako pokušala demistificirati, a nastojanje vladajućih usmjerilo se na konkretne postupke koji su mogli koristiti u borbi protiv epidemije. Koliko god da je važno definirati je li bolest zarazna (podrazumijevajući širenje kontaktom) ili „epidemijska” (što se odnosi na teoriju o mijazmama i antikontagionizam) ili oboje, još je važnije poduzeti mjere za koje je iskustvo pokazalo da su korisne u suzbijanju bolesti. ${ }^{69}$ Naputak iz 1848. bio je namijenjen isključivo lokalnim vlastima i medicinskom osoblju koje upravlja epidemijama na lokalnoj razini te se ističu brojne njihove dužnosti: osiguravanje dovoljne količine lijekova, organizacija hospitalizacije socijalno ugroženih, nadzor postupanja s preminulima, inspekcijske provjere provođenja svih vrsta propisanih mjera. Posebno važna dužnost okružnoga liječnika bilo je podnošenje tjednih izvještaja; ističe se da je proces promatranja epidemije veoma važan jer se iz „točne dijagnoze dominantne epidemije i nalaza utvrđenih njenim uzrokom može odrediti način liječenja i kvaliteta medicinskih mjera" ${ }^{70}$ Većina teksta Naputka stoga sadržava upute o

\footnotetext{
65 Lanza, Relazione nosografico-statistica sull'epidemia colerosa, 60-61.

${ }^{66}$ Lanza, Relazione nosografico-statistica sull'epidemia colerosa, 60-61.

67 Lanza, Relazione nosografico-statistica sull'epidemia colerosa, 30-31.

${ }_{68}$ HR-DAZD-386-Štampe, kut. 46, sv. 8, Zadar, (bez datuma) 1836. Upute o ponašanju i postupanju kod zaraznih bolesti, osobito kolere, čl. 2. Epidemija koja je poharala Europu u vrijeme revolucija 1848./49. smatra se kolerom koja se počela širiti 1839. iz Indije s britanskim trupama preko Kine, srednje Azije, arapske obale, Kaspijskoga i Crnoga mora do Carigrada i dalje po Europi i Americi. Speck, „Cholera”, 647.

${ }^{69}$ HR-DAZD-386-Štampe, kut. 46, sv. 8, Zadar, (bez datuma) 1836. Upute o ponašanju i postupanju kod zaraznih bolesti, osobito kolere, čl. 16.-17.

${ }^{70}$ HR-DAZD-fond 386-Štampe, kut. 46, svezak 8, Zadar, (bez datuma) 1836. Upute o ponašanju i postupanju kod zaraznih bolesti, osobito kolere, čl. 12 .
} 
sastavljanju izvještaja, pa se osim iznimno detaljnih pitanja na koja liječnik ima obratiti pozornost donose i tabelarni obrasci. Od praktičnih preventivnih i kurativnih postupaka i mjera uglavnom se ponavljaju oni koji su vrijedili u naputcima iz 1831. i 1835. godine: ističe se važnost umjerenih prehrambenih navika, posebno se preporučuje izbjegavanje konzumacije nezreloga i pokvarenoga voća, „loše” vode, te izbjegavanje tjelesnoga pothlađivanja. Uz umjeren način života, savjetuje se držati okolinu čistom, a u slučaju prvih simptoma bolesti uobičajeno pročišćavanje prostora provjetravanjem, isparavanjima i ispiranjima octom, te utopljivanje bolesnika, poticanje znojenja i blaga terapija kamilicom, sljezom i gorušicom do dolaska liječnika. ${ }^{71}$ Uspostavljanje karantena, sanitarnih kordona i segregacija oboljelih ne spominju se ni u tom naputku, a takve su mjere do 1848 . napuštene i u mnogim europskim državama. ${ }^{72}$

I daljnje djelovanje dalmatinskih vlasti bilo je potpuno u skladu s antikontagionističkom i mijazmatičkom teorijom. U listopadu 1849., obraćajući se puku proglasom na narodnom jeziku, predviđa se razbuktavanje epidemije kolere $\mathrm{u}$ Dalmaciji jer donji vitrovi puvaju, a navlastito jug, te se kao „vanjski” uzrok kolere navodi ustajao zrak koji isparava s' baretinah, s' vodah smerdljivih, s' gadah, buništah i smrada nagomilana kod kućah. ${ }^{73}$ Proglasom se opasnost od epidemije pokušala umanjiti točnim tvrdnjama da kolera pokatkad poštedi i odsike istoga grada ali varoša u kom bisni, no tu pojavu pogrešno tumačeći kao selektivnu i individualnu sklonost oboljenju u određenim vanjskim okolnostima (poput atmosferskih prilika i načina života). ${ }^{74}$ Iako je vlada tim proglasom ponovno uputila na pridržavanje prethodnih naputaka, posebno onih o zabrani karantena, na nekim mjestima u Dalmaciji lokalno je stanovništvo, čini se, ipak pribjeglo tom uvriježenom protuepidemijskom mehanizmu. ${ }^{75}$ Dalmatince je trebalo uvjeravati da središnja vlada djeluje prema naputcima savjetodavnoga tijela sastavljenog od najuglednijih liječnika Monarhije, koje nije preporučilo uspostavljanje karantene. Razlog odustajanja od karantenskih mjera, ističe se u Glasniku dalmatinskom, nije šteta koju bi mogla pretrpjeti trgovina, nego „tjelesno blagostanje puka”. ${ }^{76}$

${ }^{71}$ HR-DAZD-fond 386-Štampe, kut. 46, svezak 8, Zadar, (bez datuma) 1836. Upute o ponašanju i postupanju kod zaraznih bolesti, osobito kolere, čl. 2-3.

72 Evans, „Epidemics and Revolutions”, 142.

73 „Raspis Na C. K. Kapetanie okolišne, činovnike političke, upraviteljne, obćinske, čuvare zdravlja, Pripoštovana cerkovna starešinstva, župnike i duhovnike u Deržavi”, Glasnik dalmatinski (Zadar), br. 39, 15. 10. 1849.

74 "Raspis Na C. K. Kapetanie okolišne, činovnike političke, upraviteljne, obćinske, čuvare zdravlja, Pripoštovana cerkovna starešinstva, župnike i duhovnike u Deržavi”, Glasnik dalmatinski (Zadar), br. 39, 15. 10. 1849.

${ }^{75}$ „Objavljenje tičuće se ukinuća kontumacie postavljene u nikim mistima Dalmacie protiv bolesti Koleri”, Glasnik dalmatinski, br. 50, 22. 11. 1849.

${ }^{76}$ „Kad se Kolera 1847 godine prikučivala Samoderžavju (Cesarovini), bivša C.K. Pridvorna Kančelaria skupila je bila vištih likarah, da odrede kakve bi se zaprike mogle na putu staviti, da se 
Postavljene karantene, osim što su bile nezakonite, pokazatelj su nepovjerenja puka u "mudrost Vlade“ i njegove neprihvatljive „samovoljnosti”. ${ }^{77} \mathrm{U}$ istom proglasu od 22. studenog 1849. vlasti u duhu antikontagionističke teorije ipak prognoziraju brzi svršetak epidemije ... ,jer je sa svim nestalo Kolere u gradu Terstu, i u njegovoj okolini, a u ovom glavnom gradu sad samo ridko i slabo koga vata, te do malo i ovde će je za cilo nestati, buduć da se već aer prominio.“78

Moguće je da se paradigma vlasti izmijenila djelomično i pod utjecajem medicinske struke: teorije o etiologiji kolere u medicinskoj znanosti sredinom 19. stoljeća postajale su sve složenije. Izložio ih je liječnik Valentino Trigari u knjižici izdanoj 1851. u Splitu. ${ }^{79}$ Trigari je obavljao liječničku praksu u Zadru 1849. te je od svojih kolega bio optužen da je previdio prve slučajeve kolere, a knjigu je napisao da bi obranio svoju profesionalnu čast. Pozivajući se na brojne medicinske autoritete počevši od Hipokrata, a najviše na svojega suvremenika, talijanskoga liječnika Francesca Puccinottija, ${ }^{80}$ Trigari je obrazložio različite uzroke i manifestacije kolere. Za razliku od Lanze, razlikovao je zapadnu od azijske kolere. Zapadnu je smatrao autohtonom u Europi, a javljala se uslijed određenih atmosferskih prilika (dugotrajno toplo ili toplo i vlažno vrijeme; nagle promjene vremena iz jako vrućega u jako hladno i obratno) te zbog načina života (stanja duha poput potištenosti, straha, depresije; alkoholizam, određene prehrambene prilike i navike). Zapadna kolera, za razliku od azijske, nije se smatrala zaraznom. ${ }^{81}$ Azijskom kolerom smatrao je oblik kolere koji se svijetom proširio iz Indije 1817. godine. ${ }^{82}$ Vanjska manifestacija obiju kolera gotovo je sasvim jednaka, a jedina razlika u simptomima jest izostanak cijanoze kod zapadnoga oblika bolesti. ${ }^{83}$ Trigari, kao i Lanza, opisuje karakteristiku sporadičnoga pojavljivanja (azijske)

neuvali ona bolest u Austrianske deržave. (...) Pridvorna sjedinjena Kančelaria po rasudi podpuno virodostojnih likarah nije kontumacie protiv Koleri naredila, to se tako ona nije vladala zbog štete koja bi mogla tergovinu postignuti, nego zbog pritežitih uzrokah, koji se uprav tiču tilesnoga blagostanja pukah (...).” "Objavljenje tičuće se ukinuća kontumacie postavljene u nikim mistima Dalmacie protiv bolesti Koleri”, Glasnik dalmatinski (Zadar), br. 50, 22. 11. 1849.

77 "Objavljenje tičuće se ukinuća kontumacie postavljene u nikim mistima Dalmacie protiv bolesti Koleri”, Glasnik dalmatinski (Zadar), br. 50, 22. 11. 1849.

78 "Objavljenje tičuće se ukinuća kontumacie postavljene u nikim mistima Dalmacie protiv bolesti Koleri”, Glasnik dalmatinski (Zadar), br. 50, 22. 11. 1849.

79 Trigari, Memoria sopra i primi casi di Cholera-morbus.

${ }_{80}$ Francesco Puccinotti bio je ugledni i zaslužni talijanski liječnik koji je kao suvremenik epidemije kolere sredinom 1830-ih napisao raspravu o toj bolesti. „Puccinotti, Francesco”, Treccani, pristup ostvaren 3. 11. 2020., https://www.treccani.it/enciclopedia/francesco-puccinotti_(Dizionario-Biografico)/.

81 Zapadna kolera prema uzrocima se dijeli na još tri vrste: hipersteničnu, hiposteničnu i nadražujuću, no manifestacija svih triju potpuno je ista. Trigari, Memoria sopra i primi casi di Cholera-morbus, 27-28, 52-53.

82 Trigari, Memoria sopra i primi casi di Cholera-morbus, 32-33.

83 Trigari, Memoria sopra i primi casi di Cholera-morbus, 53-54. 
kolere, tj. pojavu gdjekojega slučaja koji može biti zarazan, no bez masovnoga širenja epidemije. ${ }^{84}$ Lanza ipak ne spominje termin „epidemijski genij” (genio epidemico) kolere, koji Trigari uvelike koristi u značenju principa koji se razvija kao posljedica kemijskih i kozmo-telurskih procesa, pripisujući mu ključnu ulogu u širenju i pogubnosti epidemije. ${ }^{85} \mathrm{Na}$ temelju te ideje (koja izvorno proizlazi iz Hipokratova opusa i humoralne medicine) razlikuje jednostavne nezarazne, sezonske („konstitucijske”) epidemije uzrokovane atmosferskim prilikama, koje se mogu javljati često, te razorne zarazne epidemije poput azijske kolere uzrokovane „epidemijskim genijem”, koji je potreban da se zapali „zarazni mamac” (esca contagiosa). ${ }^{86}$ Navodeći primjere epidemija kuge iz prošlosti, Trigari ističe da epidemijskom geniju treba duže razdoblje da se razvije u pogubnu epidemiju. Period od 14 godina, koliko je prošlo od prethodne pandemije azijske kolere, ${ }^{87}$ ne smatra dovoljnom vremenskom distancom, pa tu činjenicu, među ostalim, koristi kao argument za svoju tezu da prvi slučajevi epidemije u Zadru 1849., kao ni kasnija oboljenja te godine, nisu bili posljedica azijske nego zapadne kolere. ${ }^{88}$

Trigari je našao i brojne druge argumente da bi potvrdio svoju tezu. Od prva četiri slučaja kolere u Zadru 1849., jedina koja je obrazložio, za troje ljudi tvrdi da su oboljeli i preminuli od zapadne kolere, a jedan je, po Trigarijevu mišljenju, patio od upale želuca.$^{89}$ Među simptomima oboljelih od kolere, tvrdi Trigari, nije bilo cijanoze ni „mramorne pothlađenosti”, karakterističnih za azijsku koleru, ${ }^{90}$ a stanje u kojem su se našli - zapadnu koleru, objasnio je složenim i međusobnim utjecajem atmosferskih prilika u Zadru te godine, ${ }^{91}$ tjelesne konstitucije oboljelih, ${ }^{92}$ nji-

${ }^{84}$ Lanza je kao primjer sporadične pojave kolere naveo primjer zaraženoga mladića iz Trogira 1834., uslijed čega je došlo do zaraze manjega opsega u mladićevoj okolini, no bez većega epidemijskog širenja. Lanza, Relazione nosografico-statistica sull'epidemia colerosa, 52-53. Trigari, Memoria sopra i primi casi di Cholera-morbus, 42-43, 53, 57-58.

85 Trigari, Memoria sopra i primi casi di Cholera-morbus, 16-20, 53.

86 Trigari, Memoria sopra i primi casi di Cholera-morbus, 17.

87 Epidemija kolere u Dalmaciji odvijala se 1836., pa se Trigari uzimajući u obzir 14 (a ne 13) godina od posljednje epidemije vjerojatno referira na onu u Italiji, koja je počela 1835. godine.

88 Trigari, Memoria sopra i primi casi di Cholera-morbus, 20, 42, 53.

89 Trigari, Memoria sopra i primi casi di Cholera-morbus, 58.

90 Trigari, Memoria sopra i primi casi di Cholera-morbus, 49-51.

91 Prema Trigariju, te godine u Zadru nije bilo izvanrednih i neobičnih atmosferskih okolnosti osim suše, koja ljudski organizam čini podložnim razvoju parazita u gastrointestinalnom traktu. Trigari, Memoria sopra i primi casi di Cholera-morbus, 47, 55-56.

92 „Zbog jadnog stanja u kojemu je pronađen” jednom od oboljelih nije bilo moguće utvrditi „temperament”, no činilo se da je „emotivno osjetljiv astenik, a samim tim i slabe fizičke građe”. Drugi je pacijent imao „melankoličan karakter” te je bio „atletske građe”. Trigari, Memoria sopra i primi casi di Cholera-morbus, $8,10$. 
hova duševnoga stanja ${ }^{93}$ te načina života u danima prije obolijevanja. ${ }^{94}$ Također je tvrdio da u Zadru nakon tih četvero spomenutih nije bilo sličnih slučajeva bolesti idućih 40 dana, „čak ni u bolnicama”, što sigurno ne bi bio slučaj da se radilo o vrlo zaraznoj azijskoj koleri. ${ }^{95}$

Takav Trigarijev diskurs vrlo je pragmatičan s obzirom na to da je njime želio opravdati svoje profesionalne postupke te je u suprotnosti s prihvaćenom teorijom o periodizaciji i podrijetlu epidemija kolere u 19. stoljeću. U nekoj se mjeri ipak podudara s očitovanjima tadašnje dalmatinske vlade, koja su bila izrazito oprezna, suzdržana, a ponekad i kontradiktorna u pitanju epidemije koja je harala Zadrom 1849. godine. Je li bilo nekih lokalnih odstupanja tijekom pandemije kolere 1848. - 1849., pitanje je koje će zbog ograničenja retroaktivne dijagnostike teorijskim alatima ostati neodgovoreno.

\section{Kolera u Zadru 1849. godine}

Kolera u Zadru 1849. spominje se i u drugim izvorima koji su bilježili vremenski tijek razvoja i širenja epidemije, ponajprije broj oboljelih, izliječenih i preminulih. U zadarskom ljetopisu Federico Bianchi navodi da se bolest pojavila 2. rujna kod nekih ljudi koji su u Zadar došli iz Venecije. Situacija se smirila do početka prosinca te su po prestanku epidemije 1. prosinca otvorene sve obrazovne institucije. ${ }^{96}$ Isti datum, 2. rujna, kao početak epidemije naznačuje i Glasnik dalmatinski, a kao izvor zaraze navode se dva mornara koja su u Zadar došla iz Venecije. Obilježja bolesti i smrtni ishodi počeli su se ubrzo pojavljivati i kod drugih, a da je riječ o koleri liječnici su potvrdili nakon 10. rujna, kad je istoga dana oboljelo osam osoba. ${ }^{97}$ Nakon pojave prve novinske vijesti izvještaji o koleri - o broju zaraženih, preminulih i izliječenih - javljaju se u svakom broju Glasnika sve do 12. studenog, kada je prenoseći vijesti od 6. studenog objelodanio da već dva dana nisu zabilježeni novi oboljeli te da se preostali zaraženi dobro oporavljaju. ${ }^{8}$ Prema priloženim podacima, u Zadru je ukupno oboljelo 95 osoba, od kojih je preminulo 39.99

\footnotetext{
${ }_{93}$ Za ženu koja je njegovala jednoga od oboljelih Trigari tvrdi da se razboljela uslijed prevelikoga straha od kolere, a to je uzbuđenje onda izazvalo daljnje specifične biološke reakcije u tijelu. Trigari, Memoria sopra i primi casi di Cholera-morbus, 49-50.

94 Trigari je pomno opisao loše prilike u Veneciji te godine, odakle su doplovila prva dva zaražena muškarca, njihovo iscrpljujuće putovanje te prehranu tijekom plovidbe. Treći oboljeli, student prava Pietro Franceschi, u kratkom vremenu prije obolijevanja iscrpio se učenjem za završne ispite, a zatim i izlaganjem hladnom zraku. Trigari, Memoria sopra i primi casi di Cholera-morbus, 8-10.

95 Trigari, Memoria sopra i primi casi di Cholera-morbus, 48, 92.

96 Carlo Federico Bianchi, Fasti di Zara (Zara: Tipografia di G. Woditzka, 1888), 146.

${ }_{97}$ Glasnik dalmatinski (Zadar), br. 42, 25. 10. 1849., 1.

98 Glasnik dalmatinski (Zadar), br. 47, 12. 11. 1849., 1. Vijesti o broju zaraženih objavljene su: 29. 10. 1849. (br. 43, 2), 1. 11. 1849. (br. 44, 1), 5. 11. 1849. (br. 45, 2) i 8. 11. 1849. (br. 46, 1).

99 Glasnik dalmatinski (Zadar), br. 46, 8. 11. 1849., 1.
} 
Matične knjige umrlih zadarskih župa donose drugačije podatke, koji omogućavaju i podrobniju historiografsku analizu. Ipak, valja istaknuti da se razmjeri epidemije 1849. usporedbom podataka Glasnika i matičnih knjiga, ali i s obzirom na pomanjkanje ostalih izvornih podataka i saznanja, ne mogu precizno odrediti. Za utvrđivanje razmjera epidemije može međutim poslužiti komparacija sa zabilježenim i historiografski istraženim podacima o epidemijama desetljeće prije (1836.) i poslije (1855.) (tablica 1). ${ }^{100}$

Tablica 1. Broj oboljelih, izliječenih i umrlih od kolere u Zadru 1836., 1849. i 1855. godine

\begin{tabular}{|c|c|c|c|c|}
\hline & $\begin{array}{c}1836 . .^{101} \\
(8.9 .-8.10 .)\end{array}$ & $1836 .{ }^{102}$ & $1849 .{ }^{103}$ & $\begin{array}{c}1855.104 \\
(22.6 .-13.12 .)\end{array}$ \\
\hline Oboljeli & 272 & 273 & 145 & 118 \\
\hline Izliječeni & 149 & 107 & 78 & 28 \\
\hline Umrli & 123 & 166 & 67 & 90 \\
\hline
\end{tabular}

Za razliku od podatka zabilježenih u novinama, koji navode ukupno 39 preminulih od kolere, matične knjige umrlih pokazuju brojeve slične iskazanima u tablici 1 te tijekom 1849. navode 62 osobe preminule od kolere. ${ }^{105}$ Podatke o uzrocima smrti u matičnim knjigama možemo smatrati vjerodostojnima jer su mrtvozor-

\footnotetext{
${ }^{100}$ Službeni podaci o broju stanovnika samoga grada Zadra 1849. nisu utvrđeni. Prema objavljenim službenim statističkim podacima, u gradu je 1845. živjelo 6747 stanovnika, a 1851. njih 7555 . Usp. Tafeln zur Statistik der oesterreichischen Monarchie (Wien: k. k. Hof- und Staatsdruckerei, 1856), 16; Valentino Lago, Memorie sulla Dalmazia (Venezia: G. Grimaldo, 1870), 299; Vera Graovac, „Populacijski razvoj Zadra", Geoadria 9 (2004), br. 1: 60. Nedostatak statističkih podataka o stanovništvu Dalmacije i Zadra u razdoblju 1830. - 1850. posvjedočuje i rad Lovorke Čoralić, „Prilog proučavanju demografskog razvoja Dalmacije i Zadra tridesetih i četrdesetih godina 19. stoljeća”, Radovi Zavoda za hrvatsku povijest Filozofskoga fakulteta Sveučilišta u Zagrebu 23 (1990), br. 1: 81-88. Važno je napomenuti da podatke o stanovništvu Zadra (grada, općine, kotara, okruga) u promatranom razdoblju ne donosi ni monumentalno djelo Ante Bralića i Mithada Kozličića, Stanovništvo Kraljevine Dalmacije prema službenim izračunima i popisima 1828. - 1857. (Zadar: Sveučilište u Zadru, 2012).

${ }^{101}$ Lanza, Relazione nosografico-statistica sull'epidemia colerosa, 79.

${ }_{102}$ Šime Peričić et. al., Zadar za austrijske uprave (Zadar: Matica hrvatska - ogranak u Zadru, 2011), 136.

${ }^{103}$ Peričić et. al., Zadar za austrijske uprave, 137.

${ }^{104}$ Peričić et. al., Zadar za austrijske uprave, 137.

${ }^{105}$ HR-DAZD-378 - Zbirka matičnih knjiga, Matična knjiga mrtvih Sv. Stošija 1847. - 1849., Inv. br. 1523; Matična knjiga mrtvih Sv. Stošija 1849. - 1853., Inv. br. 1524; Matična knjiga mrtvih Sv. Šime 1848. - 1861., Inv. br. 1803; Matična knjiga mrtvih Sv. Ilija 1835. - 1869., Inv. br. 1808; Matična knjiga mrtvih Sv. Ilija 1849. - 1884., Inv. br. 1809. Svim navedenim matičnim knjigama može se pristupiti preko mrežnih stranica Državnoga arhiva u Zadru (https:/www.dazd.hr/hr/knjige/maticne-knjige).
} 
ništvo obavljali liječnici u javnoj gradskoj službi, ${ }^{106}$ što nas navodi na zaključak da se u vladinu glasilu manipuliralo podacima. Nadalje, podaci iz matičnih knjiga o počecima zaraze u skladu su sa spomenutim Trigarijevim izvještajem. Prvi slučajevi smrti od kolere (da colera morbus) upisani su u maticu 6. rujna, a riječ je 20-godišnjem pravniku (legale) Pietru Franceschiju rodom iz Omiša i sobarici Luciji Collogna staroj 43 godine, koja je podrijetlom bila iz Tridenta. S obzirom na to da su preminuli živjeli na istoj adresi (calle di San Giorgio), vjerojatno se radi o sluškinji koju spominje Trigari, koja je preminula brinući se za jednoga oboljelog (Franceschi). ${ }^{107}$

Promatrajući usporedno epidemijsku godinu i godine prije i nakon nje, 1849. zabilježena je povećana smrtnost.

Grafikon 1. Broj umrlih u Zadru 1848., 1849. i 1850. godine

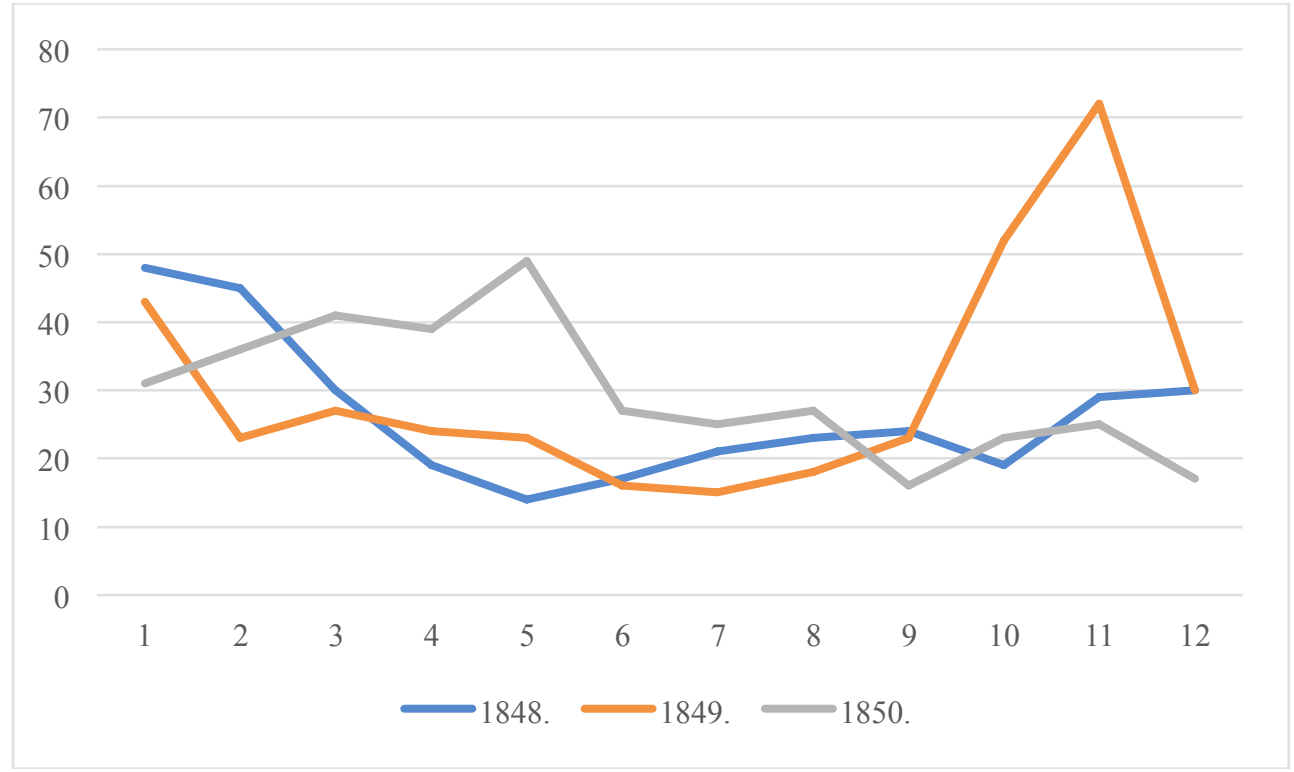

Kao što je vidljivo iz grafikona 1, broj umrlih tijekom 1849. porastao je u odnosu na prethodnu godinu za $14,7 \%$, a u odnosu na 1850 . bio je veći za $2,7 \%$. Krizu mortaliteta 1849. potvrđuju i drugi demografski pokazatelji, u prvom

\footnotetext{
${ }^{106}$ Usp. Tatjana Buklijaš, Nenad Vekarić, „Mortalitet u Cavtatu (1825. - 1918.)”, Anali Zavoda za povijesne znanosti HAZU u Dubrovniku 36 (1998): 319-320.

107 Vidi bilj. 93 i 94. Prijenos bolesti bio je moguć preko pranja odjeće zaraženog. Snowden, Epidemics and Society, 243. HR-DAZD-378 - Zbirka matičnih knjiga, Matična knjiga mrtvih Sv. Stošija 1847. 1849., upisi 157 i 158.
} 
redu stopa mortaliteta i negativna stopa prirodne promjene (tablica 2). Iznimno visoke i iznadprosječne stope mortaliteta zabilježene su sve tri godine, $\mathrm{s}$ time da je vrhunac smrtnosti bio upravo 1849 . godine. ${ }^{108}$ Zabilježena je i visoka stopa negativne prirodne promjene $(-12 \%)$ kao posljedica veće smrtnosti nego rodnosti.

Tablica 2. Procjena broja stanovnika i stope mortaliteta u Zadru 1848. - 1850.

\begin{tabular}{|l|c|c|c|c|}
\hline \multicolumn{1}{|c|}{ Godina } & $\begin{array}{c}\text { Broj stanovnika } \\
\text { (procjena) }^{109}\end{array}$ & Natalitet $^{110}$ & Mortalitet & $\begin{array}{c}\text { Prirodna } \\
\text { promjena }\end{array}$ \\
\hline $\mathbf{1 8 4 8 .}$ & 7150 & $42 \%$ o & $44 \%$ o & $-2,5 \%$ o \\
\hline $\mathbf{1 8 4 9 .}$ & 7285 & $38 \%$ o & $50 \%$ o & $-12 \%$ o \\
\hline $\mathbf{1 8 5 0 .}$ & 7420 & $36 \%$ o & $48 \%$ o & $-11,1 \%$ o \\
\hline
\end{tabular}

Da je upravo kolera bila razlog povećanja smrtnosti svjedoče i stope porasta u mjesecima kada je epidemija zabilježena u matičnim knjigama - rujan, listopad i studeni - kada se smrtnost u odnosu na godinu prije povećala za $122,7 \%$, a u odnosu na 1850. godinu $129,6 \%$.

Tijekom 1849. prosječan broj umrlih po mjesecima bio je 30,5 , naspram 26,5 prosječno umrlih 1848. i 29,6 1850. godine. Brojem umrlih većim od prosjeka ističu se studeni (72) i listopad (52) te siječanj (43), a kao što je već očito, uzrok jesenskoga povećanja smrtnosti bila je kolera. ${ }^{11}$

${ }^{108}$ Usp. Jakov Gelo, Demografske promjene u Hrvatskoj od 1780. do 1981. (Zagreb: Globus, 1987), 147148.

${ }^{109}$ S obzirom na to da za promatrane godine nije sačuvan podatak o broju stanovnika Zadra, izračuni demografskih pokazatelja dobiveni su na temelju procjene broja stanovnika metodom linearne interpolacije. Vidi i bilj. 100.

${ }^{110}$ Natalitet je izračunat na temelju matičnih knjiga krštenih Sv. Stošije, Sv. Šimuna i Sv. Ilije koje se nalaze na mrežnoj stranici Državnoga arhiva u Zadru.

${ }^{111}$ Siječanj bilježi iznadprosječnu smrtnost u svim promatranim godinama, što je u skladu s općim demografskim trendovima, a kao najčešći uzroci smrti u siječnju 1849. navode se zarazne bolesti, većinom tuberkuloza te „bolesti disala”, primjerice kronični bronhitis (bronchite cronica), upala pluća (polmonite) i upala plućne ovojnice (pneumonite). Usp. Buklijaš, Vekarić, „Mortalitet u Cavtatu (1825. - 1918.)", 322, bilj. 23. 
Grafikon 2. Mjesečna distribucija umrlih 1849. godine

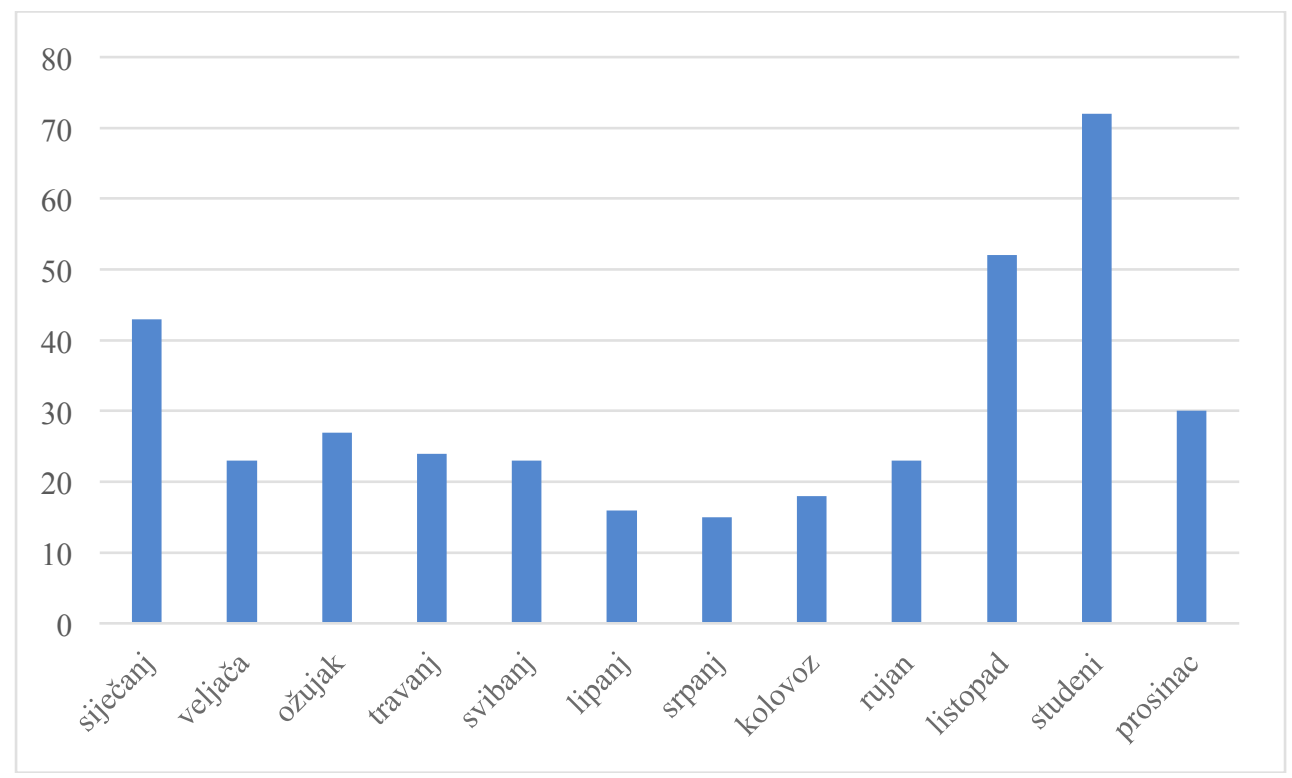

Po uzrocima smrti 1849. godina bila je u skladu s općim demografskim trendovima - sa zaraznim bolestima kao prevladavajućom skupinom pogubnih bolesti (37,6 \%) (grafikon 3). ${ }^{112}$ Kolera je, očekivano, oduzela najviše života, s udjelom od $48,1 \%$ u zaraznim bolestima. Tuberkuloza, bolest od koje je u osvit modernoga doba umrlo najviše ljudi u svijetu ${ }^{113}$, bila je uzrok smrti $34,8 \%$ ljudi preminulih od zaraznih bolesti. ${ }^{114}$

\footnotetext{
112 Podjela bolesti napravljena je prema klasifikaciji iz 1906. (Vladimir Katičić, ur., Sbirka zakona i naredaba tičućih se zdravstva i zdravstvene službe. Dodatak I: Za vrieme od 1. siečnja 1905. do 1. travnja 1906. (Zagreb: Zdravstveni odsjek Kr. zemaljske vlade, 1906)), koja bolesti raspoređuje u 20 skupina. S obzirom na to da se u određenom broju upisanih uzroka smrti korištena klasifikacija pokazala „premodernom”, navlastito u slučajevima nedovoljno definiranih simptoma (vrućica, grčevi), kreirali smo (u skladu s metodološkim obrascem koji su prezentirali N. Vekarić i T. Buklijaš) skupinu "nerazvrstanih bolesti”. U toj se skupini najčešće navodi spasmo i difficile dentizione. Usp. Buklijaš, Vekarić, „Mortalitet u Cavtatu (1825. - 1918.)”, 320-324.

${ }^{113}$ Buklijaš, Vekarić, „Mortalitet u Cavtatu (1825. - 1918.)”, 322, bilj. 23 ili npr.: Milan Radošević, „O dizenteriji, ospicama, sifilisu, šarlahu i tifusu u Istarskoj provinciji za talijanske međuratne uprave (1918. - 1940.)", Problemi sjevernog Jadrana 14 (2005): 56, bilj. 3.

${ }^{114} \mathrm{~S}$ udjelom većim od $1 \%$ od zaraznih se bolesti još spominju gastroenteritis te (trbušni) tifus (febbre tifoidea). Sa po jednim spomenom smrt je nastupila od angine, ospica, sifilisa, febbre perniciosa - malarične groznice i tetanusa.
} 
Grafikon 3. Najčešći uzroci smrti u Zadru 1849. godine

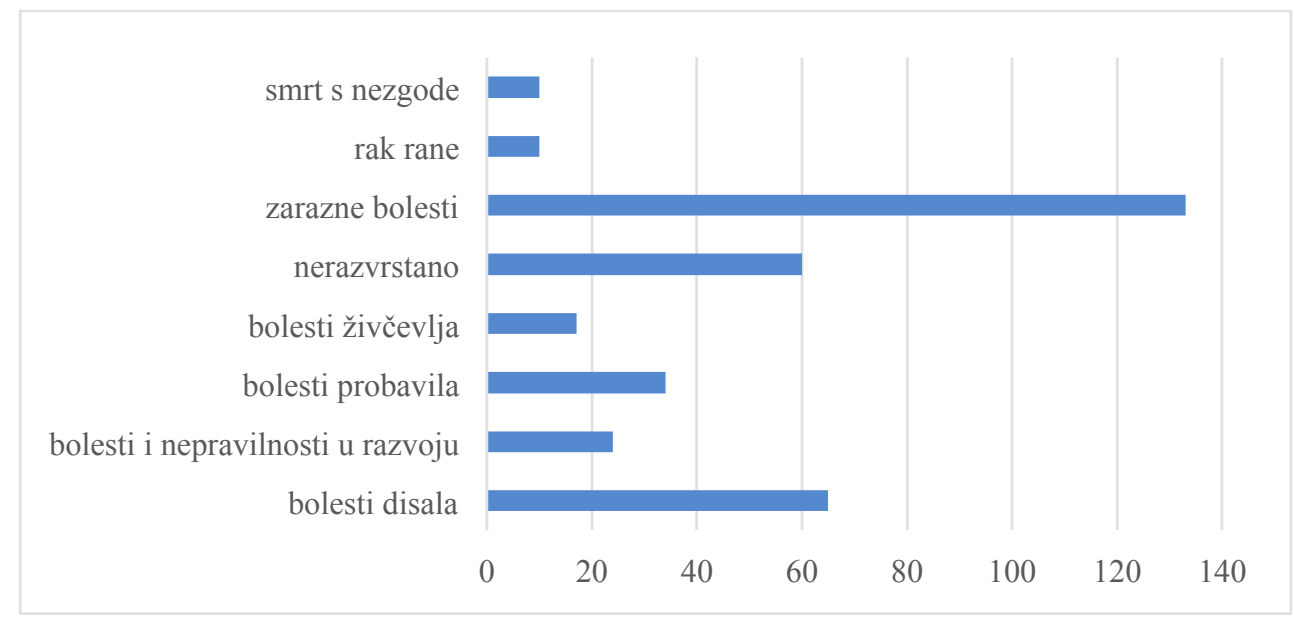

Grafikon 4. Najčešće zarazne bolesti u Zadru 1849. godine

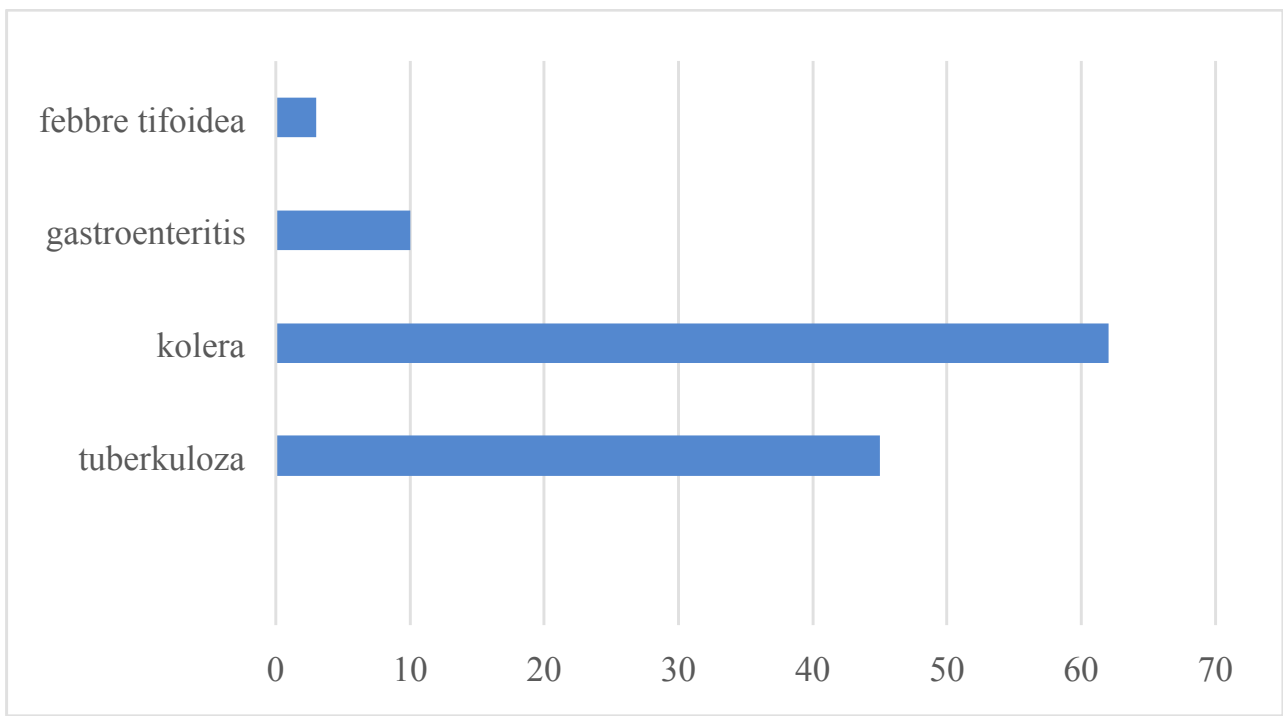

Prvi smrtni slučaj od kolere upisan je 6. rujna, a posljednji spomen u maticama zabilježen je 26. studenog 1849. godine (grafikon 5). U prosjeku je u zabilježene dane umiralo dvoje ljudi, a vrhunac smrtnih slučajeva bio je 9. studenog, kada je upisano sedam smrti. S obzirom na naglu pojavu bolesti i brzo razvijanje simptoma možemo zaključiti da je vrhunac zaraze bio upravo od 9. do 14. studenog. ${ }^{115}$

\footnotetext{
${ }^{115}$ Frederick F. Cartwright, Michael Biddiss, Bolest i povijest (Zagreb: Naklada Ljevak, 2006), 140; Evans, „Blue Funk and Yellow Peril”, 111-112; Snowden, Epidemics and Society, 235-236. Evans je procijenio da oko polovine zaraženih i premine od kolere.
} 
Grafikon 5. Dnevna raspodjela umrlih od kolere

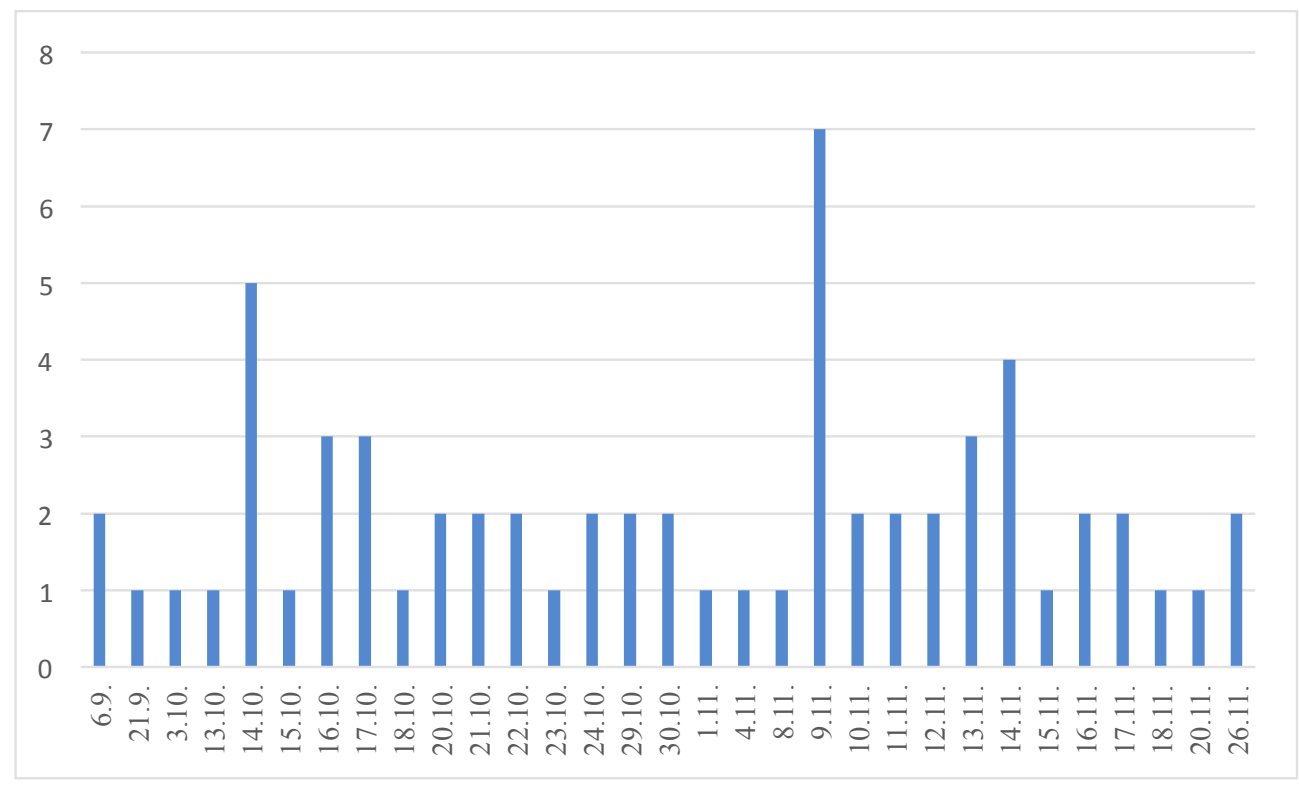

Što se tiče spolne strukture, od kolere je umrlo nešto više žena (51,6 \%) nego muškaraca $(48,4 \%)$, dočim su u ukupnom broju preminulih 1849. muškarci bili zastupljeni sa 50,7 \%, a žene sa 49,3\%. Prosječna dob umrlih za cijelu promatranu godinu bila je 32 godine - žene su prosječno živjele 31,8 godina, a muškarci nešto manje - 29,9 godina. Prosječna starost umrlih od kolere bila je viša i iznosila je 35,5 godina. Žene umrle od kolere imale su prosječno 36,7 godina, a muškarci 34,4 godine.

Prema demografskim obrascima utemeljenim na istraživanjima kolere, epidemija je sa smrtnim ishodom pogađala najviše najmlađe te stanovništvo srednje i starije životne dobi. Smrtnost potonjih dobnih skupina bila je povezana s velikom mogućnosti zaraze na poslovima i zanimanjima gdje se moglo doći u doticaj sa zaraženom vodom (muškarci zaposleni kao lučki radnici, mornari i slično, a žene u kućanstvu). Visoka je bila i smrtnost djece do pet godina starosti, a s kolerom su se najbolje „nosili” adolescenti i mlađe stanovništvo. ${ }^{116}$

Ako promotrimo dobne skupine umrloga stanovništva u Zadru, možemo zaključiti da je najveća smrtnost bila u fertilnim dobnim kontingentima, od 15. do 49. godine (59,9 \%), i to za oba spola. Unutar te skupine najviše je smrti zabilježeno u starosnim skupinama 20 - 24 i 40 - 44 godine (za žene) i 45 - 49 godina (za muškarce). Starije stanovništvo (od 50. godine) bilo je zastupljeno sa $24,1 \%$, a u tim je dobnim kontingentima, u skladu s općim trendovima vezanim uz žensku

${ }^{116}$ Evans, „Blue Funk and Yellow Peril”, 114. Usp. i: Železnik, „Koper in kolera leta 1855”, 592-593. 
dugovječnost, bilo zastupljeno 66,6 \% žena. Najstarija osoba preminula od kolere (9. studenog 1849.) bila je Vicka Vlahović podrijetlom s Iža, koja je umrla u dobi od 70 godina. Najmlađi preminuli bio je dječak - Giovanni Bianchi, koji je živio na piazetta marina na kućnom broju 116, a bile su mu tri godine. ${ }^{17}$

Najmlađi dobni kontingent - dojenčad i djeca - zastupljen je u najmanjem postotku (16,1\%), a riječ je o desetero preminule djece, s podjednakom zastupljenošću obaju spolova. Iako je, u skladu s općim demografskim trendovima, dojenački mortalitet bio visok - 15,2 \% umrlih tijekom 1849. nije doživjelo prvu godinu - među uzrocima dojenačke smrti nije navedena kolera. ${ }^{118}$ Razlog odstupanja od spomenutih europskih trendova (posebice za dojenačku dob) vjerojatno leži u nedovoljno preciznoj dijagnostici zabilježenoj pri smrti - čak je trinaestero dojenčadi i troje mlađe djece (1, 2 i 5 godina) preminulih u epidemijskim mjesecima s „općim uzrocima” smrti (spasmo, convulsione, difficile dentizione) iza kojih se možda skrivala kolera. ${ }^{119}$ Takav je vjerojatno bio slučaj smrti jednogodišnje Karoline Marinello, koja je preminula 12. studenog 1849., a pod uzrok smrti upisano je difficile dentizione. Dan prije, 11. studenog, od kolere je preminula njezina starija sestra, petogodišnja Iginia (otac obiju djevojčica bio je Anđelo Marinello, a živjele su u ulici sv. Frane na kućnom broju 665). ${ }^{120}$

Dječaci umrli od kolere pripadali su kontingentu do 4 godine, a djevojčice preminule od kolere u prosjeku su imale 6,5 godina. Za preminulu djecu pomoću podataka iz matičnih knjiga u samo dva slučaja pronađena je obiteljska relacija koja bi svjedočila o horizontalnom širenju kolere. Tako je sedmogodišnja Perina Rančić preminula dva dana nakon oca Šimuna (39). Za oboje preminulih navedeno je da su se u Zadar doselili da pochi giorni, a živjeli su u ulici san Demetrio 125. ${ }^{121} \mathrm{U}$ istom periodu od kolere je preminuo Vicko Prestini star 4 i pol godine (14. studenog), sin Nadaline Trigari, koja je 9. studenog preminula u 48. godini. ${ }^{122}$

${ }_{117}$ HR-DAZD-378 - Zbirka matičnih knjiga, Matična knjiga mrtvih Sv. Stošija 1847. - 1849., upisi 230 i 240 .

${ }^{118}$ S obzirom na to da je 63,6 \% dojenčadi umrlo od nedovoljno definiranih dijagnoza spasmo i difficile dentizione, postoji vjerojatnost da se i iza tih smrti krije kolera (iako je samo 13 dojenčadi umrlo u epidemijskim mjesecima).

119 Evans, „Blue Funk and Yellow Peril”, 115.

${ }^{120}$ HR-DAZD-378 - Zbirka matičnih knjiga, Matična knjiga mrtvih Sv. Stošija 1847. - 1849., upisi 241 i 243.

${ }^{121} \mathrm{Na}$ istom je kućnom broju 10. studenog preminula i Perina Cassan (30), ali u ovoj fazi istraživanja nije jasna poveznica s gore spomenutima. HR-DAZD-378 - Zbirka matičnih knjiga, Matična knjiga mrtvih Sv. Stošija 1847. - 1849., upisi 239, 249 i 252.

${ }^{122}$ Trigari je bilo Nadalinino djevojačko prezime, a kao suprug i Vickov otac naveden je Lovro Prestini. Na istom kućnom broju, calle di san Demetrio 146, zabilježena je i smrt od kolere Magdalene Rossan 16. studenog iste godine. HR-DAZD-378 - Zbirka matičnih knjiga, Matična knjiga mrtvih Sv. Stošija 1847. - 1849., upisi 231, 254 i 260. 
Grafikon 6. Dobno-spolna raspodjela umrlih od kolere

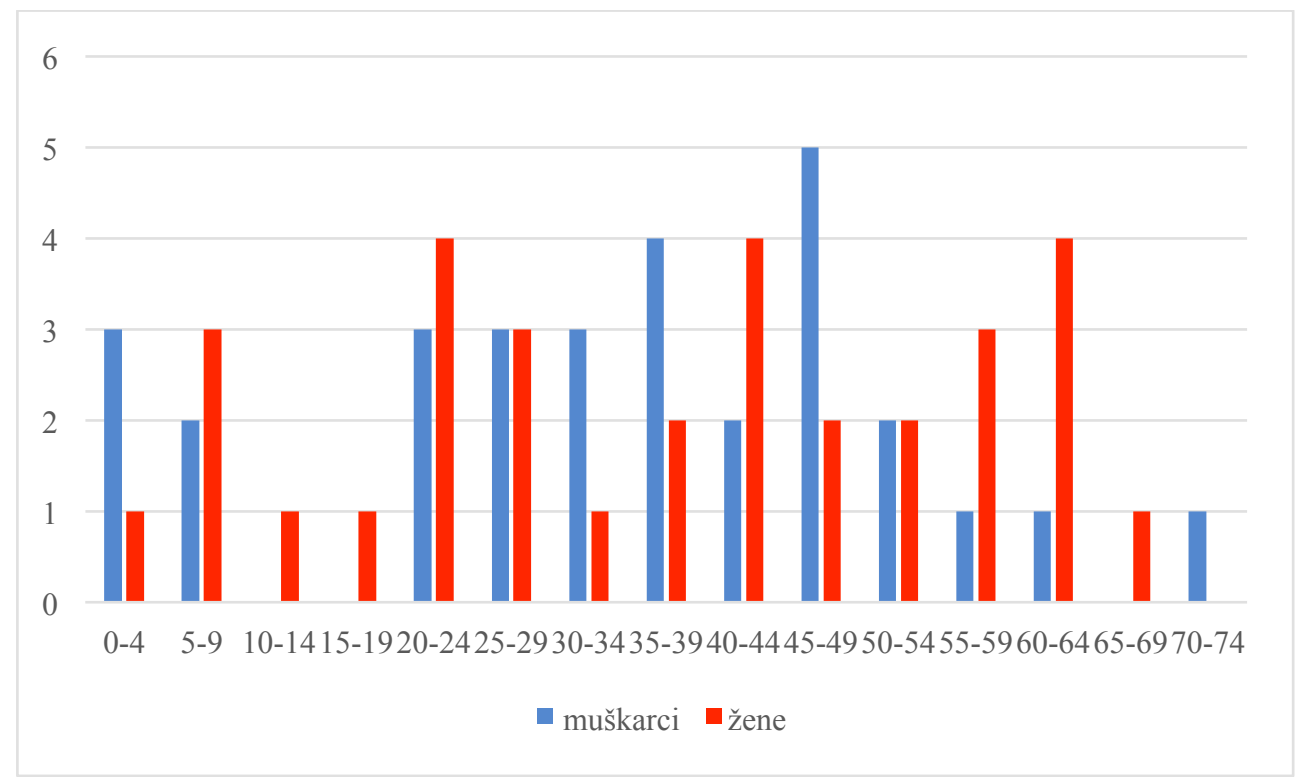

Za razmatranje teze o povezanosti kolere i loših stambenih i životnih uvjeta (koji su uključivali skučen životni prostor i velik broj ukućana, neodgovarajuću prehranu, higijenu te opskrbu vodom), odnosno sa siromašnijim društvenim slojevima, poslužit će nam analiza zanimanja i društvenoga statusa preminulih. ${ }^{123}$ Mogućnosti analize ovoga istraživačkog pitanja sužene su iz više razloga, koji se ponajprije odnose na promatrani uzorak. Kao i kod drugih analiziranih tema, matične knjige nisu zabilježile oboljele, nego samo preminule od kolere. U maticu umrlih nisu se redovito upisivala ni zanimanja, posebice za žene, kojima je u toj rubrici upisana obiteljska relacija (udovica, supruga, neudana). I za preminulu djecu kao statusna relacija ponekad je navedeno zanimanje oca. ${ }^{124}$ Uzimajući u obzir sve te prepreke, mogu se donijeti određeni uopćeni zaključci. U skladu s iznesenom tezom, preminuli od kolere većinom su pripadali nižem društvenom i socijalnom sloju. To je posebice vidljivo u prikazu zanimanja i statusa premi-

${ }^{123}$ Tijekom prve polovine 19. stoljeća zahvaljujući brojnim zakonskim regulativama poboljšana je javna higijena grada. Brinulo se o čistoći ulica, za koju su bili zaduženi svi stanovnici grada. Ulice su bile uske i mračne, nisu bile sasvim popločene, a kanalizacije nije bilo. Da bi se spriječilo širenje zaraze, pojavila je inicijativa za izgradnju gradskoga groblja izvan gradskih zidina. Međutim, najveći je problem bila redovita opskrba čistom vodom, prije svega održavanje vode u gradskim cisternama te nedostatak pitke vode u ljetnim mjesecima. Izgradnja gradskoga vodovoda trajala je nekoliko godina i izvodila se u više faza. Najprije je sagrađen vodovod od izvora Botina do Trga pet bunara (1838.), a voda se punila u cisterne na Trgu pet bunara i na Trgu tri bunara. Potom je 1844. vodovod produljen do Zelenoga trga (Piazza dell'Erbbe), a dvije godine poslije razgranat je po čitavom gradu. Usp. Peričić et al., Zadar za austrijske uprave, 74-76, 134, 135; Snowden, Epidemics and Society, 234, 244.

${ }^{124}$ Najčešće je bilo riječ o djeci čiji su očevi bili obrtnici. 


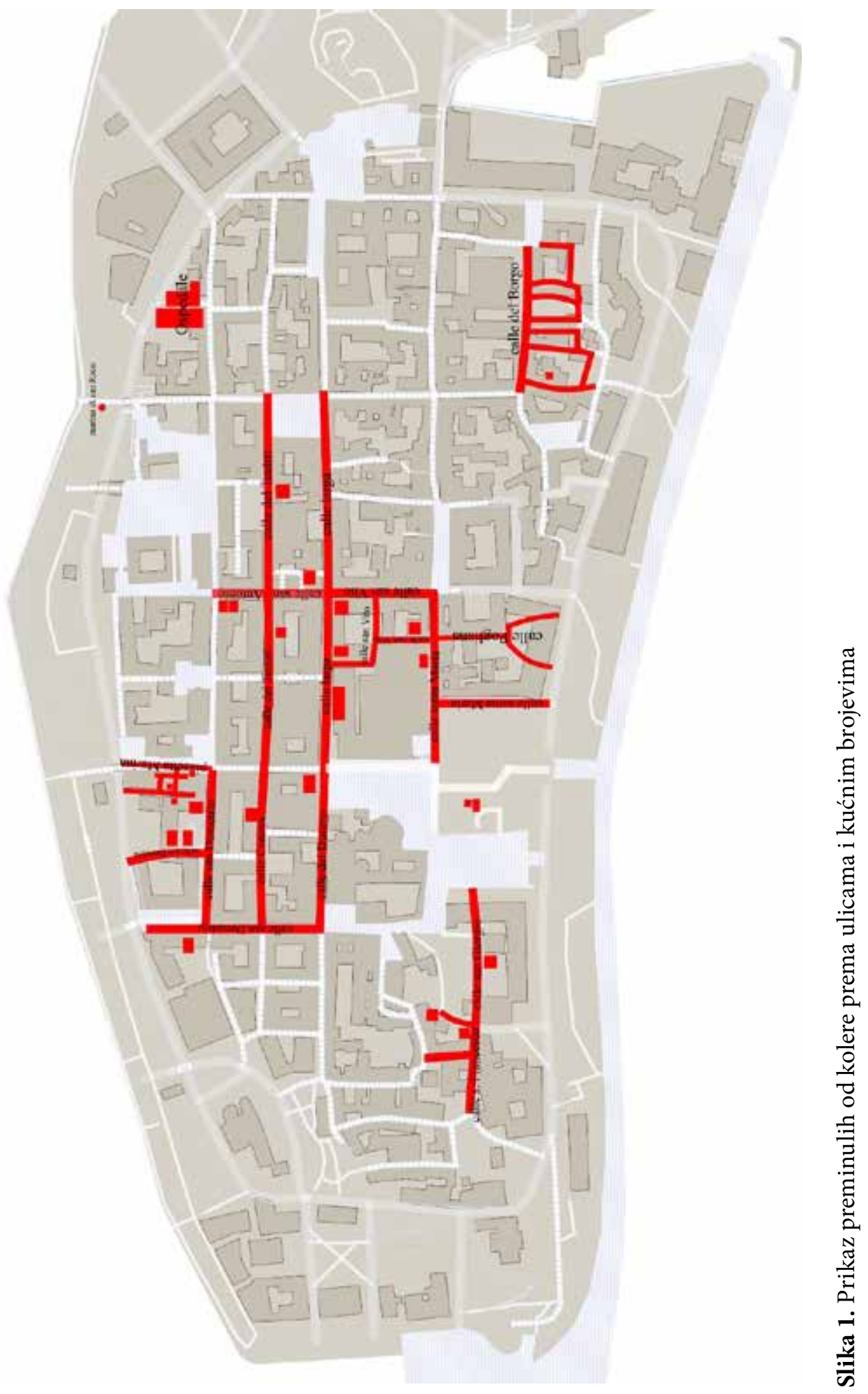


nulih žena, od kojih je bilo sedam sluškinja, a od njih su dvije navedene i kao nahodi (espurea). Uz njih su preminule i jedna pralja te sobarica i primalja. O nižem statusu umrlih žena svjedoče i tri od kolere preminule „sirote” (povera). Preostalim je ženama navedena obiteljska relacija ili status supruge, udovice ili neudane djevojke. Muška su zanimanja raznovrsnija, ali ih je zajednički predznak, a ponegdje i navedeni status, svrstavao u niže društvene slojeve. Preminuli od kolere tako se bilježe kao nahodi, posluga, nosači, a spominju se i po jedan prosjak (accattone) i osuđenik (condannato criminale). Zamjetna skupina preminulih muškaraca bavila se sitnim obrtničkim zanimanjima, a najviše je bilo postolara (3) te po jedan pekar i kalafat. ${ }^{125} \mathrm{Uz}$ prvopreminuloga studenta prava (Pietra Franceschija) od kolere je preminuo i jedan odvjetnik (avvocato) te profesor crtanja u normalki (scuola normale). ${ }^{126}$

Razmatranje mjesta boravišta preminulih od kolere mogla bi nam rasvijetliti dodatna saznanja o načinu prijenosa i širenja bolesti u gradu. Valja napomenuti da je postavljeno pitanje kompleksno te je za potpunu sliku potrebno sagledati širi društveni kontekst života i umrežavanja onodobnoga stanovništva, primjerice analizirati konkretnije životne i prostorne uvjete u pojedinim dijelovima grada, grupiranje određenih društvenih skupina i zanimanja u prostoru, kao i gustoću naseljenosti pojedinih zadarskih predjela. Potpuniju sliku svakako bi dali podaci o oboljelima koji nisu poimenično sačuvani u izvorima. Stoga je prostorni prikaz preminulih samo naznaka širenja epidemije 1849. godine.

Matična knjiga umrlih bilježila je dva prostorna identifikatora pojedinca - patria e domicilio. Prvi se odnosio na mjesto podrijetla (rođenja), a drugi na mjesto, odnosno adresu stanovanja u samom gradu. Ovo posljednje bilo je naznačeno za $62,9 \%$ preminulih od kolere, s time da je od toga udjela za $14,5 \%$ naznačena samo ulica bez kućnoga broja. ${ }^{127}$

Kako se vidi iz karte (slika 1), prikaz preminulih prema ulicama i kućnim brojevima ne pokazuje izraženije koncentriranje. ${ }^{128}$ Brojem preminulih ističu se za-

${ }^{125}$ Iako obrtnici predstavljaju heterogenu skupinu zanimanja, u svojem su poslu često bili okruženi nečistoćom, vodom, raznim otpadcima, što je svakako povećalo mogućnost zaraze. Železnik, „Koper in kolera leta 1855", 601.

${ }^{126}$ Usp. slične zaključke u: Katarina Keber, „Epidemija kolere na Kranjskem med mestom in podeželjem. Primjer Ljubljane in župnije Slavina na notranjskem leta 1855”, Ekonomska i ekohistorija 2 (2006), br. 2: 70-71; Evans, „Blue Funk and Yellow Peril”, 116, Železnik, „Koper in kolera leta 1855”, 598-602.

${ }^{127} \mathrm{Za} 10$ preminulih kao mjesto rođenja i boravka zapisan je Zadar (nato e domiciliato di Zara), a za 11 njih zabilježeno je samo mjesto rođenja, odnosno podrijetla. Za jednu preminulu navodi se kao mjesto podrijetla Zagreb (Zagabria), a za jednu Morinj u Boki kotorskoj. Ostali preminuli podrijetlom su bili iz šire zadarske okolice (Iž, Neviđane, Obrovac) ili Dalmacije (Šibenik, Murter, Drniš, Promina).

${ }^{128}$ Kao predložak za izradu karte, označavanje ulica i kućnih brojeva korištena je suvremena topografska karta Zadra. U nju su na temelju katastarske izmjere Zadra 1825. - 1827. ucrtane i označene ulice i kuće (označene kvadratom) u kojima su zabilježene osobe preminule od kolere. HR-DAZD-382 - Up- 
padni i središnji dio grada, koji je uključivao ulice sv. Demetrija ( 9 preminulih), Canova (3 preminula) i piazetta marina (3 preminula). Ulica sv. Demetrija najzornije prikazuje horizontalno širenje zaraze unutar obitelji s obzirom na to da je više smrti zabilježeno na kućnim brojevima 125 i 146 te u susjednim kućama na brojevima 128 i $129 .{ }^{129}$ I osobe preminule u ulici Canova na kućnom broju 277 bile su iz iste obitelji. Riječ je o udovici Katarini Bersa (rođena u Kranjskoj), koja je od kolere preminula 17. listopada u 58. godini. Nekoliko dana prije nje preminule su i njezine kćeri, Filipa (rođena u Kotoru, preminula 14. listopada u 21. godini) i Klementina (rođena u Splitu, preminula 16. listopada u 20. godini). U ostalim je ulicama zabilježeno maksimalno troje preminulih, međutim prostorna i obiteljska poveznica među njima nije utvrđena. Zanimljivo je napomenuti i da je u bolnici zabilježena smrt samo dviju osoba: nahoda Perine (prezime nije navedeno) i udovice Matije Chiuza. ${ }^{130}$

\section{Zaključak}

Najopsežnije mjere opreza za slučaj pojave kolere propisane su u Dalmaciji u fazi iščekivanja epidemije, od 1830. do 1835. godine. Istovremeno, u jeku rasprave o etiologiji kolere, predviđena je mobilizacija svih dotad prakticiranih postupaka za sprječavanje širenja bolesti bez obzira na to jesu li se temeljili na teoriji kontagionizma ili antikontagionizma; to je uključivalo karantene, sanitarne kordone i segregacijske postupke. Ipak, 1836., kada se razbuktala prva epidemija kolere u Dalmaciji, vlada je zabranila uspostavu karantena, sanitarnih kordona i segregaciju priklanjajući se tako, unatoč suprotnim mišljenjima nekih lokalnih liječnika poput Francesca Lanze, dominantnoj antikontagionističkoj teoriji. Kada se kolera ponovno raširila Europom u vrijeme revolucija 1848. i 1849., pa i u Dalmaciji 1849., vlasti Habsburške Monarhije u svojim su očitovanjima pokušavale umanjiti opasnost na razne načine te su uglavnom izbjegavale koristiti termin „kolera” koliko je to bilo moguće. Dalmatinska vlada nije bila transparentna ni u izvještajima o broju umrlih od kolere u svojem glasilu; objavljena brojka znatno je manja od ukupnoga broja preminulih zabilježenih u matičnim knjigama umrlih. U jednom su ipak bili jasni i konkretni: zabranjene su karantene i sanitarni kordoni, i to pod utjecajem medicinske struke, kako su isticali iz vlade, no svakako i zbog trgovačkih interesa, što su nijekali.

Čini se da tijekom epidemije kolere 1849. u Dalmaciji nije bilo složnog i dobro organiziranog protuepidemijskog djelovanja. Karantene i kordoni u nekim mje-

\footnotetext{
rava za katastarsku izmjeru, 1823. - 1839., br. 577, Zadar-Grad, 1825. - 1827. Ovom prilikom zahvalile bismo dr. sc. Antunu Nekiću na pomoći u prikupljanju citiranoga izvora.

${ }^{129}$ Slučajevi navedeni u bilj. 115 i 116.

${ }^{130}$ Perina je preminula 26. studenog, a Matija Chiuza 20. listopada 1849. HR-DAZD-378 - Zbirka matičnih knjiga, Matična knjiga mrtvih Sv. Stošija 1847. - 1849., upisi 200 i 275.
} 
stima ipak su se uspostavljali, a nakon stroge zabrane, pretpostavljamo, morali su se dokidati. Zadarski liječnici na početku epidemije nisu se slagali da se radi o koleri, pa je došlo do međusobnih optuživanja. Povrh toga, usporedimo li dvije studije o dvije epidemije kolere u Dalmaciji, 1836. i 1849., Lanzinu i Trigarijevu, možemo također zaključiti da su teorije o etiologiji kolere s vremenom postale kompleksnije, pri čemu se teško postizao konsenzus čak i među stručnjacima.

Epidemiju kolere u Zadru 1849. ponajbolje može opisati izjava koperskoga okružnog liječnika: Il Coléra non rasparmiò età ${ }^{131}$ Trajala je tri mjeseca (od rujna do kraja studenoga) i odnijela 62 života. Zadesila je podjednako i muškarce i žene te sve dobne skupine, posebice fertilnu. S obzirom na etiologiju bolesti, najugroženiji i epidemijom najzahvaćeniji bili su pojedinci nižega društvenog sloja i imovinskoga stanja, čiji su životni, stambeni i poslovni uvjeti pogodovali bržem, jačem i intenzivnijem razvoju bolesti.

${ }^{131}$ Preuzeto iz: Železnik, „Koper in kolera leta 1855”, 593. 


\section{Neobjavljeni izvori}

Hrvatska - Državni arhiv u Zadru, Zadar - 378 - Zbirka matičnih knjiga (HRDAZD-378).

Hrvatska - Državni arhiv u Zadru, Zadar - fond 382 - Uprava za katastarsku izmjeru (HR-DAZD-382).

Hrvatska - Državni arhiv u Zadru, Zadar - fond 386 - Štampe (HR-DAZD-386).

Hrvatska - Znanstvena knjižnica Zadar, Zadar - Avvertimento diretto alla popolazione Dalmata sul Colera, Zara, 16. ottobre 1835, Misc. B 8212 (HR-ZKZD, Misc. B 8212).

Hrvatska - Znanstvena knjižnica Zadar, Zadar - Istruzione per gli assistenti degli ammalati di colera morbus, Zara, 14. ottobre 1831, Misc. B 8199 (HR-ZKZD, Misc. B 8199)

Hrvatska - Znanstvena knjižnica Zadar, Zadar - Istruzione per le II. RR. Commissioni locali di sanita, gli II. RR. Capitanati circolari e le alter autorita politiche rispetto al Colera morbus, Zara, 25 settembre 1831, Misc. B 8198 (HR-ZKZD, Misc. B 8198).

\section{Objavljeni izvori i literatura}

Bertoša, Slaven. „Zapisi o koleri u jednoj istarskoj župi god. 1855.” Historijski zbornik XLI (1988): 245-251.

Bianchi, Carlo Federico. Fasti di Zara. Zara: Tipografia di G. Woditzka, 1888.

Bolonić, Mihovil. „Kužne bolesti u prošlosti otoka Krka (s posebnim osvrtom na koleru 1855. godine)". Krčki zbornik 6 (1975): 79-132.

Bralić, Ante; Kozličić, Mithad. Stanovništvo Kraljevine Dalmacije prema službenim izračunima i popisima 1828. - 1857. Zadar: Sveučilište u Zadru, 2012.

Brunton, Deborah. „Dealing with Disease in Populations. Public Health, 18301880". U: Medicine Transformed. Health, Disease and Society in Europe, uredila Deborah Brunton, 180-210. Manchester: University Press, 2004.

Buklijaš, Tatjana. „Kolera: 'nova' bolest u doba revolucija”. Hrvatska revija 3 (2003), br. 1: 90-93.

Buklijaš, Tatjana; Vekarić, Nenad. „Mortalitet u Cavtatu (1825. - 1918.)”. Anali Zavoda za povijesne znanosti HAZU u Dubrovniku 36 (1998): 303-420.

Cartwright, Frederick F.; Biddiss, Michael. Bolest i povijest. Zagreb: Naklada Ljevak, 2006. 
Cigui, Rino. „Antiche e nuove paure: le epidemie di colera a Trieste e in Istria nel secolo XIX”. Atti 38 (2008), br. 1: 429-504.

Čoralić, Lovorka. „Prilog proučavanju demografskog razvoja Dalmacije i Zadra tridesetih i četrdesetih godina 19. stoljeća". Radovi Zavoda za hrvatsku povijest Filozofskoga fakulteta Sveučilišta u Zagrebu 23 (1990), br. 1: 81-120.

Despot, Igor. „Kolera u Banskoj Hrvatskoj 1913. godine - mjere državne vlasti u prevenciji i suzbijanju epidemije". Radovi Zavoda za hrvatsku povijest Filozofskoga fakulteta Sveučilišta u Zagrebu 45 (2013), br. 1: 59-70.

Evans, Richard J. „Blue Funk and Yellow Peril: Cholera and Society in Nineteenth-Century France". European History Quarterly 20 (1990), br. 1: 111-126.

Evans, Richard J. „Epidemics and Revolutions: Cholera in Nineteenth-Century Europe”. Past \& Present 120 (1988), br. 1: 123-146.

Fantina, Ivan. HR DAZD - 386 Štampe 1488. - 1940. Zadar: Hrvatski državni arhiv, 2006.

Fatović-Ferenčić, Stella; Wokaunn, Mario. „Poneretvlje kao patološki topos: tisak i politizacija sjećanja na doba kolere 1886. g." Liječnički vjesnik 134 (2012), br. 5-6: 186-191.

Gelo, Jakov. Demografske promjene u Hrvatskoj od 1780. do 1981. Zagreb: Globus, 1987.

Glasnik dalmatinski (Zadar), 39, 42-47, 50 (1849).

Graovac, Vera. „Populacijski razvoj Zadra”. Geoadria 9 (2004), br. 1: 51-72.

Harrison, Mark. Disease and the Modern World: 1500 to the present day. Cambridge: Polity, 2004.

Horbec, Ivana. Zdravlje naroda - bogatstvo države. Prosvijećeni apsolutizam i počeci sustava javnoga zdravstva u Hrvatskoj. Zagreb: Hrvatski institut za povijest, 2015.

Ipšić, Irena. „Demografske i društveno-gospodarske posljedice epidemije kolere - primjer epidemije u Drenovcima 1873. godine”. Scrinia Slavonica 10 (2010), br. 1: 527-545.

Juzbašić, Vinko. „Kolera u Bošnjacima 1913. godine”. Hrašće: časopis za književnost, umjetnost i povijest 28 (2003): 76-80.

Katičić, Vladimir, ur. Sbirka zakona i naredaba tičućih se zdravstva i zdravstvene službe. Dodatak I: Za vrieme od 1. siečnja 1905. do 1. travnja 1906. Zagreb: Zdravstveni odsjek Kr. zemaljske vlade, 1906.

Keber, Katarina. „Epidemija kolere na Kranjskem med mestom in podeželjem. Primjer Ljubljane in župnije Slavina na notranjskem leta 1855”. Ekonomska i ekohistorija 2 (2006), br. 2: 65-73. 
Lago, Valentino. Memorie sulla Dalmazia. Venezia: G. Grimaldo, 1870.

Lanza, Francesco. Relazione nosografico-statistica sull'epidemia colerosa, che invase la Dalmazia nell' anno 1836. Trieste: Weis, 1838.

McGrew, Roderick E. Russia and the Cholera. Madison: University of Wisconsin Press, 1965.

Muzur, Amir. „Istarski sveti Rok: od zaštitnika od kuge do zaštitnika od kolere”. U: Epidemične bolezni v Istri 19. in 20. stoletju = Le malattie epidemiche in Istria tra ' 800 e ' $900=$ Zarazne bolesti u Istri tijekom 19. i 20. stoljeća, uredio Ante Škrobonja, 69-78. Koper: Humanistično društvo Histria, 2010.

Peričić, Šime; Stagličić, Marija; Travirka, Antun; Rados, Zvjezdana; Rabac-Čondrić, Glorija. Zadar za austrijske uprave. Zadar: Matica hrvatska, Ogranak Zadar, 2011.

Ponte, Euro. „Il colera del 1886 a Muggia”. U: Epidemične bolezni v Istri 19. in 20. stoletju = Le malattie epidemiche in Istria tra ' 800 e ' $900=$ Zarazne bolesti u Istri tijekom 19. i 20. stoljeća, uredio Ante Škrobonja, 79-87. Koper: Humanistično društvo Histria, 2010.

Porter, Dorothy. Health, Civilization and the State: A history of public health from ancient to modern times. London: Routledge, 1999.

Porter, Roy. The Greatest Benefit to Mankind: A Medical History of Humanity from Antiquity to the Present. London: Fontana Press, 1997.

„Puccinotti, Francesco”. Treccani. Pristup ostvaren 3. 11. 2020. https://www.treccani.it/enciclopedia/francesco-puccinotti_(Dizionario-Biografico)/.

Puljizević, Kristina. U ženskim rukama. Primalje i porođaj u Dubrovniku (18151918). Zagreb; Dubrovnik: Zavod za povijesne znanosti HAZU u Dubrovniku, 2016.

Radošević, Milan. „O dizenteriji, ospicama, sifilisu, šarlahu i tifusu u Istarskoj provinciji za talijanske međuratne uprave (1918. - 1940.)". Problemi sjevernog Jadrana 14 (2005): 55-81.

Rothenberg, Gunther E. „The Austrian Sanitary Cordon and the Control of the Bubonic Plague: 1710-1871". Journal of the History of Medicine 28 (1973), br. 1: 15-23.

Skenderović, Robert. „Zdravstvene reforme Marije Terezije u slavonskom Provincijalu i Generale normativum sanitatis iz 1770." Scrinia Slavonica 5 (2001), br. 1: 115-143.

Snowden, Frank. Epidemics and Society: From the Black Death to the Present. New Haven; London: Yale University Press, 2019. 
Speck, Reinhard S. „Cholera”. U: The Cambridge World History of Human Disease, uredio Kenneth F. Kiple, 642-649. Cambridge: Cambridge University Press, 1993.

„Srdobolja”. Hrvatska enciklopedija, mrežno izdanje. Leksikografski zavod „Miroslav Krleža”. Pristup ostvaren 20. 10. 2020. https://enciklopedija.hr/natuknica. aspx?id=57577.

Tafeln zur Statistik der oesterreichischen Monarchie. Wien: k. k. Hof- und Staatsdruckerei, 1856.

Trigari, Valentino. Memoria sopra i primi casi di Cholera-morbus che si manifestarono in Zara nel MDCCCXXXXIX con una opinione sul cholera in generale dell' anno detto. Split: Tip M. V. Piperata e figlio, 1851.

Wokaunn, Mario; Fatović-Ferenčić, Stella; Jurić, Ivan; Bekić, Marijo. „God’s Punishment or Bad Strategy: Anti-Epidemic Measures in the Lower Neretva Basin at the Time of Cholera in 1886". Collegium Antropologicum 36 (2012), br. 3: 987-995.

Železnik, Urška. „Kolera in urbano prebivalstvo: Koper in obalna mesta v 19. stoletju”. U: Epidemične bolezni v Istri 19. in 20. stoletju = Le malattie epidemiche in Istria tra ' 800 e ' $900=$ Zarazne bolesti u Istri tijekom 19. i 20. stoljeća, uredio Ante Škrobonja, 49-68. Koper: Humanistično društvo Histria, 2010.

Železnik, Urška. „Koper in kolera leta 1855: družbeno-demografski pogled v mestno tkivo". U: Bertošin zbornik. Zbornik u čast Miroslava Bertoše, knj. 2, uredio Ivan Jurković, 583-603. Pula; Pazin: Sveučilište Jurja Dobrile u Puli; Državni arhiv u Pazinu, 2013. 
Maja Katušić*

Kristina Puljizević***

\section{Da cholera morbus - Cholera Epidemics and Anti-Epidemic Measures in Dalmatia during the 1830s and 1840 s}

\section{Summary}

Based on numerous archival sources, newspapers, and medical records, this paper discusses and analyses cholera epidemics in Dalmatia in the mid-19th century. The level of knowledge about the disease and the anti-epidemic measures has been considered, especially their effectiveness and topicality in view of the existing and growing discussions about the aetiology of diseases. In the second part of the paper, the cholera epidemic in Zadar in 1849 has been analysed as a case study. Records of cholera in the registers of deaths in Zadar allow us to estimate the number and age, gender, and social structure of deaths. The epidemic lasted three months and took 62 lives. It affected both men and women, and all age groups, especially the fertile one. Given the aetiology of the disease, the most endangered and most severely affected by the epidemic were the individuals of lower social and financial status, whose living and business conditions favoured a faster, stronger, and more intensive development of the disease.

Keywords: cholera, Dalmatia, Zadar, 1830s, 1840s, anti-epidemic measures, registers of deaths

Maja Katušić, Croatian Institute of History, Opatička 10, 10000 Zagreb, Croatia, E-mail: mkatusic@isp.hr

** Kristina Puljizević, Catholic University of Croatia, Ilica 242, 10000 Zagreb, Croatia, E-mail: kristina.puljizevic@unicath.hr 